\title{
Deciphering Streptococcal Biofilms
}

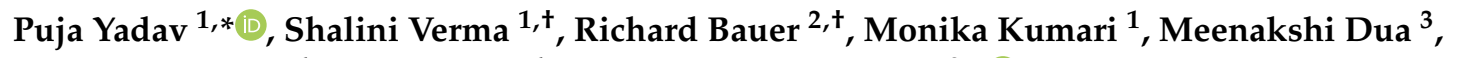 \\ Atul Kumar Johri ${ }^{4}$, Vikas Yadav ${ }^{4}$ and Barbara Spellerberg ${ }^{2, *(1)}$ \\ 1 Department of Microbiology, Central University of Haryana, Mahendergarh, Haryana 123031, India; \\ shaliniverma7993@gmail.com (S.V.); Kmonika480@gmail.com (M.K.) \\ 2 Institute of Medical Microbiology and Hygiene, University Hospital Ulm, 89073 Ulm, Germany; \\ richard.bauer@uni-ulm.de \\ 3 School of Environmental Sciences, Jawaharlal Nehru University, New Delhi 110067, India; \\ meenakshi72@hotmail.com \\ 4 School of Life Sciences, Jawaharlal Nehru University, New Delhi 110067, India; \\ akjohri14@yahoo.com (A.K.J.); vikasjnu@gmail.com (V.Y.) \\ * Correspondence: pujayadav@cuh.ac.in (P.Y.); barbara.spellerberg@uniklinik-ulm.de (B.S.) \\ + These authors contributed equally to this work.
}

Received: 19 October 2020; Accepted: 17 November 2020; Published: 21 November 2020

\begin{abstract}
Streptococci are a diverse group of bacteria, which are mostly commensals but also cause a considerable proportion of life-threatening infections. They colonize many different host niches such as the oral cavity, the respiratory, gastrointestinal, and urogenital tract. While these host compartments impose different environmental conditions, many streptococci form biofilms on mucosal membranes facilitating their prolonged survival. In response to environmental conditions or stimuli, bacteria experience profound physiologic and metabolic changes during biofilm formation. While investigating bacterial cells under planktonic and biofilm conditions, various genes have been identified that are important for the initial step of biofilm formation. Expression patterns of these genes during the transition from planktonic to biofilm growth suggest a highly regulated and complex process. Biofilms as a bacterial survival strategy allow evasion of host immunity and protection against antibiotic therapy. However, the exact mechanisms by which biofilm-associated bacteria cause disease are poorly understood. Therefore, advanced molecular techniques are employed to identify gene(s) or protein(s) as targets for the development of antibiofilm therapeutic approaches. We review our current understanding of biofilm formation in different streptococci and how biofilm production may alter virulence-associated characteristics of these species. In addition, we have summarized the role of surface proteins especially pili proteins in biofilm formation. This review will provide an overview of strategies which may be exploited for developing novel approaches against biofilm-related streptococcal infections.
\end{abstract}

Keywords: streptococci; opportunistic pathogen; planktonic; biofilm; antibiotic therapy; quorum sensing (QS)

\section{Introduction}

Biofilms are surface-associated microbial communities enclosed within a self-produced matrix consisting of a single or multiple bacterial species [1]. Following the evolution of prokaryotes several billion years ago, the evolution of biofilms is considered a defense mechanism against harsh environmental conditions by providing homeostasis and protection to the involved bacterial cells [2]. Biofilms were first observed on tooth surfaces by Antoni van Leeuwenhoek in the 17th century, while the term "biofilm" was introduced into medical microbiology by Costerton in 1982 [3]. He reported biofilm formation of S. aureus on an infected endocardial pacemaker. 
Biofilms play a prominent role in human infections. More than $80 \%$ of microbial diseases have been linked to biofilm formation. Bacterial biofilms are involved in infections of the urinary tract, the female genital tract, the bloodstream, and the upper respiratory tract [4-6]. Dental plaque, which contains streptococci and may eventually result in caries, is a prime example of a natural biofilm composed of a multispecies bacterial community.

In biofilms, increased resistance to or tolerance of antibiotics is a common problem. It may be intrinsic due to the microbial growth conditions or it may be caused by mutations or the exchange of antibiotic resistance genes [7,8]. As biofilms adapt to survive antibiotic treatment, infections are hard to eradicate despite proper antibiotic therapy $[6,9,10]$.

Most streptococcal species reside as commensals on mucous membranes, while several pathogenic streptococci are responsible for life-threatening human infections. The production of biofilms is a common phenotype of commensal as well as pathogenic species. Commensal streptococci biofilms represent their natural lifeform, and in pathogenic streptococcal species, biofilms have been identified as important determinants of infectious diseases. This review will focus on specifics of streptococcal biofilms, their regulation, and the potential to interfere with biofilm production as a therapeutic approach.

\section{Biofilm Composition}

The development of these highly ordered multicellular communities is a complex multistep process [11] (Figure 1). During biofilm formation, the bacterial cells transform from planktonic life to an immotile life form [1,12], resulting in a complex community consisting of different microbial subpopulations. Biofilm formation is initiated with the adhesion of planktonic bacteria to biotic or abiotic surfaces, the development of microcolonies, and a successive production of an extracellular matrix composed of polymeric substances such as proteins, polysaccharides, and extracellular DNA [13]. Three-dimensional structures develop through maturation and finally result in the detachment of single bacterial cells [14]. Microbial cells in biofilm experience impaired diffusion of nutrients and waste products with less nutrient availability in the core of the biofilm [15]. In addition, due to increased endogenous oxidative stress within biofilms, microbial cells are subjected to spontaneous mutations [16]. Genetic variations then give rise to microbial subpopulations that are physiologically heterogeneous $[17,18]$.

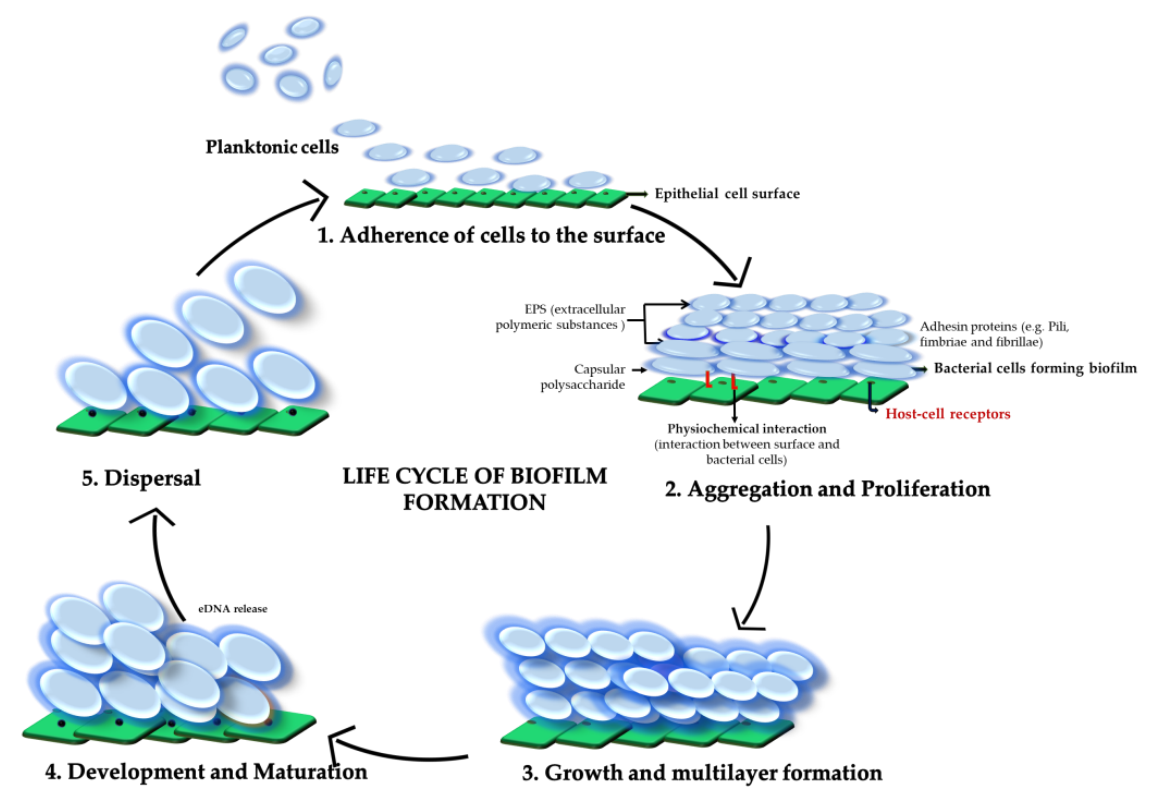

Figure 1. Schematic diagram representing the life cycle of biofilm formation in Streptococci. The diagram shows the transition of planktonic cells to sessile cells by undergoing different stages of biofilm formation and repeating the cycle by the conversion of sessile cells to the planktonic state again. 
The biofilm matrix is essential for protection of bacteria from environmental stresses and consists of extracellular polymeric substances (EPS). It represents an efficient diffusion barrier, interfering with the penetration of harmful substances inside the biofilm [1]. Differential gene expression is responsible for the production of EPS, which provides cohesion of the bacterial cells and determines the structure of the biofilm. Three major components are found in the biofilm matrix in varying amounts: extracellular polysaccharides, extracellular nucleic acids, and proteins can be detected together with a high percentage of water.

\subsection{Extracellular Polysaccharide}

Microscopic evaluation of biofilms shows exopolysaccharides as elongated or branched filaments mediating the adhesion of bacteria to other bacterial cells, host cells, and abiotic surfaces $[19,20]$. The accumulation of polysaccharide thus acts as a molecular superglue facilitating the colonization of host surfaces. Especially exopolysaccharides of the $S$. mutans biofilm matrix have been characterized in detail and mainly consist of glucans that are synthesized by specific glycosyltransferases [21]. The extracellular polysaccharides found in biofilms differ from classic streptococcal capsular polysaccharides. Especially for pneumococci, a high amount of capsular polysaccharide appears to interfere with biofilm formation, since nonencapsulated strains demonstrate a high ability to develop in vitro biofilms, while encapsulated clinical isolates and isogenic encapsulated transformants develop less biofilm than their nonencapsulated parent strains [22-25].

\subsection{Nucleic Acids}

Extracellular DNA (eDNA) is another major component of the biofilm matrix. It is highly similar to the genomic DNA of the bacterial species present within the biofilm and is released through bacterial cell lysis [26]. It plays a role in adhesion and is essential in biofilm stabilization and maintenance. Furthermore, eDNA provides protection against antimicrobial peptides and divalent cations through chelation of these substances [26]. Upon the addition of nucleases to streptococcal biofilms, significant inhibitory and disintegrating effects on biofilm formation have been observed for S. pneumonia, S. pyogenes, as well as for viridans streptococci [27-29].

\subsection{Extracellular Proteins}

The third major component in biofilm matrix, are extracellular proteins. Extracellular proteins facilitate reorganization, degradation, and dispersal of the biofilm matrix and play a structural role in biofilms [30]. A common theme for several biofilm associated proteins of Gram-positive bacteria is their ability to form amyloids. These include BAP of S. aureus, EPS of Enterococci, and P1 of S. mutans [31-33]. Amyloid proteins, which assemble into insoluble fibrils, participate supportively in cell aggregation and in biofilm formation [34]. Another form of fibrillar proteins are streptococcal pili, which are highly structured cell surface appendages consisting of several different structural proteins. Their special role in the formation of biofilms will be discussed in a later section of this review. The biofilm matrix however, also contains nonfibrillar proteins like, e.g., the Glucan-binding proteins (Gbps) in S. mutans, which play a significant role for biofilm formation as they promote aggregation and plaque cohesion [35,36]. Furthermore, some of the proteins within the biofilm matrix are enzymes involved in the degradation of EPS and the initiation of a new biofilm lifecycle. The degradation of biopolymers also delivers energy and carbon sources to bacterial biofilm cells, especially under limited nutrient availability [37].

\section{Biofilm Formation in Different Streptococci}

Many different streptococcal species including commensal as well as pathogenic streptococci form biofilms. While biofilm formation may take place under favorable environmental conditions, many species form biofilm in adverse environmental conditions as a survival mechanism to prolong their persistence under stress. 


\subsection{Betahemolytic Group A Streptococci: Streptococcus pyogenes (GAS)}

Streptococcus pyogenes (group A Streptococcus, GAS) is responsible for a wide range of human diseases worldwide including harmless affections of the skin as well as life-threatening toxic shock syndromes. The formation of biofilm on host cells and tissues contributes to its virulence and has been investigated in some detail [38,39]. L-glucose and D-mannose have been identified as major sugars of the GAS biofilms [40]. Further important components of the GAS biofilm matrix are pili and surface proteins of the MSCRAMM family mediating the adhesion to extracellular matrix components. A main characteristic of GAS biofilm formation is that it is very strain specific $[39,41]$ and that the requirements for biofilm production vary among strains $[9,41,42]$. While certain GAS strains can form biofilm on abiotic surfaces, for other strains, a matrix protein-coated surface is required [41]. Serotype M6 and M14, e.g., are able to attach to abiotic polystyrene surfaces, while other strains (M2 and M18) need collagen types I and IV, fibrinogen, fibronectin, and laminin-coated surface to establish biofilms and some strains (M1, M12, and M49) are unable to produce biofilms at all [41].

\subsection{Betahemolytic Group B Streptococci: Streptococcus agalactiae (GBS)}

Streptococcus agalactiae (Group B streptococci, GBS) causes mainly infections in neonates and adult immunocompromised patients. Similar to other streptococci, GBS has the ability to develop biofilms that facilitate colonization and survival in the host [43-46]. Biofilm formation of colonizing strains obtained from asymptomatic pregnant women was increased compared to biofilm production of strains from symptomatic patients [44]. The isolation of GBS from biofilms on intrauterine devices underlines the clinical role of GBS biofilms [47]. Acidic conditions as present in the vagina promote biofilm formation in serotype III and V strains. Especially the hypervirulent serotype III clone ST-17 is an excellent biofilm former at low $\mathrm{pH}$ [48]. Proteins play an important part and contribute to GBS biofilm structure in these strains as treatment with proteinase K disseminates the established biofilms [48].

\subsection{Betahemolytic Group C and G Streptococci: Streptococcus dysgalactiae subsp. equisimilis (SDSE)}

Streptococcus dysgalactiae subsp. equisimilis (SDSE) is closely related to S. pyogenes and causes similar infections [49]. Not many studies have been conducted on biofilm formation in this species. Resembling the situation in S. pyogenes, the biofilm-forming ability of SDSE varies with emm types. Up to $46 \%$ of clinical SDSE isolates were shown to produce biofilm with stG10.0 strains being strong biofilm producers, while emm types stG840.0, stG6.1, and stG245.0 correlate with rather weak biofilm production [50]. In addition, extracellular DNA has been implicated in biofilm formation of SDSE [51], however, SDSE has been insufficiently investigated in regard to biofilms.

\subsection{Biofilm in Non-Beta-Hemolytic Streptococci: Streptococcus pneumoniae}

S. pneumoniae colonizes the human nasopharynx and is a major bacterial pathogen for upper and lower respiratory tract infections. Biofilms have been detected on host mucosal surface in clinical settings such as pneumonia, otitis media, and rhinosinusitis [29,52-54]. Formation of biofilm is inversely correlated with capsule formation in pneumococci [53], however, the polysaccharides present in pneumococcal biofilms remain somewhat elusive. The presence of acetyl-glucosamines and ß-linked glycopyranosyl units based on positive calcofluor white staining [55] have been implicated as components of the extracellular matrix in S. pneumoniae. In addition, extracellular DNA and pili proteins ( $\operatorname{RrgA}, \operatorname{RrgB}$, and $\operatorname{Rrg} C$ ) have been documented [53]. Dispersion of S. pneumonia cells from colonizing bacterial cells in biofilms, appears to be involved in the development of invasive infections [56].

\subsection{Biofilm in Viridans Streptococci: Streptococcus mitis Group}

Streptococci of the Streptococcus mitis group, which include Streptococcus oralis, Streptococcus gordonii, and Streptococcus sanguinis are primarily commensals of the oral cavity and found as early colonizers of dental multispecies biofilms $[57,58]$. These early streptococcal colonizers are essential 
for the formation of stable multispecies dental biofilms [59]. Glucans are a major component of the extracellular matrix of oral multispecies biofilms and are synthesized through the glycosyltransferase (GTF) of S. mitis group streptococci and other oral streptococcal species. The molecular basis for glucan production in these species has been investigated in detail. S. oralis has a single GTF structural gene (gtfR), with the ability to synthesize water-soluble and -insoluble glucan using sucrose as a substrate [60]. While in S. gordonii, a single GTF encoding gene ( $g t f G)$ is positively regulated by cotranscription of $r g g$, which is present upstream of $g t f G$ [61]. S. sanguinis also has a single GTF structural gene $(g t f P)$ and synthesizes water-insoluble glucans [62]. Glucans promote the accumulation of bacteria in biofilms [63]. In oral multispecies biofilm, during later stages of biofilm development, complex intraspecies interactions may occur [64]. The cocolonization with S. mitis and S. sanguinis, e.g., enhances the biomass and the cellular metabolic activity in C. albicans biofilm and causes morphological changes in candida [65].

Apart from mucosal colonization, viridans streptococci can also cause invasive infections, which most often present as septicemia or endocarditis. Biofilm formation has been implicated as an important factor in infective endocarditis caused by streptococcal species from the S. mitis group and can be demonstrated in clinical streptococcal isolates from patients with endocarditis and sepsis [66].

\subsection{Biofilm in Viridans Streptococci: Streptococcus anginosus Group}

Streptococcus anginosus together with S. constellatus and S. intermedius constitutes the S. anginosus group (SAG). Streptococcal species of this group are found as a commensal in the oral flora, the gastrointestinal tract, the upper respiratory tract, and the urogenital tract. However, these species are also the cause of serious invasive infections including blood stream infections and abscesses. Biofilm production has been found in all of the three species [67-69], but little is known about the molecular determinants of $S$. anginosus biofilm formation. While some studies focus on the regulation aspect of biofilm in SAG $[67,68]$, a detailed investigation of the biofilm matrix has not been performed. Investigations of multispecies biofilms with S. aureus, P. aeruginosa, and S. anginosus, as they occur in cystic fibrosis patients, show that $S$. anginosus is less susceptible to antibiotics within these biofilms [70].

\subsection{Biofilm in Viridans Streptococci: Streptococcus mutans}

S. mutans proteins involved in biofilm formation include glucan-binding proteins, collagen-binding proteins, glucosyltransferases, and the cell surface protein antigen c (PAc) [36]. Adhesive glucans produced from sucrose by glucosyltransferases (GTFs), represent an essential component of the biofilm matrix in S. mutans and provide the attachment of bacterial cells to surface structures [71]. In contrast to other viridans streptococci, which most often harbor a single GTF, S. mutans produces three types of GTFs (GtfB, GtfC, and GtfD) that are necessary to maximize the level of sucrose-dependent cellular adhesion [36]. GtfB and GtfC, which synthesize predominantly water-insoluble glucans rich in 1,3-glucosidic linkages, are located on the cell surface and encoded by the $g t f B$ and $g t f C$ genes, respectively. While GtfD, which synthesizes water-soluble glucans rich in 1, 6-glucosidic linkages, has been detected in secretory proteins that is encoded by the $g t f D$ gene. Each enzyme is composed of two functional domains, an amino-terminal catalytic domain (CAT), which binds and hydrolyzes the sucrose substrate, and a carboxyl-terminal glucan-binding domain (GBD), which functions as an acceptor for binding glucan, and plays a role in defining the nature of the glucan synthesized by a GTF. Multiple glucan-binding proteins (GBPs) stabilize plaque on tooth surfaces [36,72], while the cell surface protein antigen c (PAc) of $S$. mutans mediates adherence of the bacterial cells to the tooth surfaces via salivary pellicle interaction $[36,73]$. 


\section{The Role of Pili and Streptococcal Cell Surface Proteins in Biofilm Formation (Pathogenesis and Virulence Factors)}

\subsection{Pili}

Many streptococcal species harbor long proteinaceous fibril structures on their surface known as pili, which are important during initial adhesion [74]. These pili play a critical role for virulence during host-pathogen interaction and contribute to the development of biofilms. They participate in the adhesion and invasion process of the major streptococcal pathogens of humans, S. pyogenes, S. agalactiae, and S. pneumoniae [75-78].

The pili structure is built through the covalent cross-linking of two or more pilin subunits. The major subunit (backbone protein) is assembled into the pilus by a class $C$ sortases that catalyzes the covalent attachment between a conserved lysyl residue of the pilin motif (WxxxVxVYPK) of one subunit and the conserved threonyl residue of the LPXTG motif of another subunit. In addition, one or more accessory subunits can be incorporated into the pilus backbone $[79,80]$.

Ancillary protein 1 (AP-1) is attached to the tip of the main pilus component (backbone protein), and ancillary protein-2 (AP-2) anchors the pilus to the bacterial surface. Initial contact with host tissue is mediated by AP-1, which is also important for biofilm formation [81]. In addition, AP1 promotes bacterial aggregation and thus pili not only play a role in the initial adhesion leading to intimate association with host cells but also mediate the coaggregation of bacteria as an important step in biofilm formation.

In S. pyogenes, pili have been demonstrated to be an integral part of biofilm formation, which seems to be associated with certain M- and FCT (fibronectin-binding, collagen-binding, T-antigen-binding proteins) types $[10,41,82-87]$. The S. pyogenes T-Antigens, which have been used for serological purposes over many decades, were later shown to be pili backbone antigens [88]. The FCT region is highly variable and constitutes 9 different variants [88-92].

In GAS strain TW3558 (emm6), the FCT-1 pilus region (fctX operon) consisting of pilus backbone (Tee6), ancillary protein (FctX), and sortases (SrtB and SrtA) is essential for biofilm formation suggesting that both structural as well as assembly components of pili are important for adherence and biofilm formation $[81,85,89]$ (Figure 2). While FCT type 1 strains were shown to be generally good biofilm formers, independent of media or pH-conditions, in some other FCT types, e.g., FCT-2, FCT-3, FCT-5, and FCT-6, biofilm production depends on culture conditions and low $\mathrm{pH}($ Table 1$)[83,86]$. FCT-7 and FCT- 8 are derivatives of FCT- 4 and found in a very limited number of strains, so there is no study available on their biofilm-forming ability.

Table 1. Representation of S. pyogenes pilus structure encoding in the Fibronectin-Binding, Collagen-Binding, T-Antigen (FCT) genomic region, and its effect on biofilm-forming capacity.

\begin{tabular}{cc}
\hline $\begin{array}{c}\text { FCT (Fibronectin-Binding, Collagen-Binding, } \\
\text { T-Antigen) Type Encoding pili }\end{array}$ & Biofilm Phenotype \\
\hline FCT type 1 & Strong biofilm, independent of media or pH \\
\hline FCT type 9 & Poor biofilm, under all tested condition \\
\hline FCT-2, FCT-3, FCT-5, and FCT-6 & $\begin{array}{c}\text { Biofilm phenotype dependent upon on culture } \\
\text { conditions and is triggered by low pH }\end{array}$ \\
\hline FCT type 4 & $\begin{array}{c}\text { Inhomogeneous response to environmental } \\
\text { conditions with respect to biofilm formation. }\end{array}$ \\
\hline
\end{tabular}




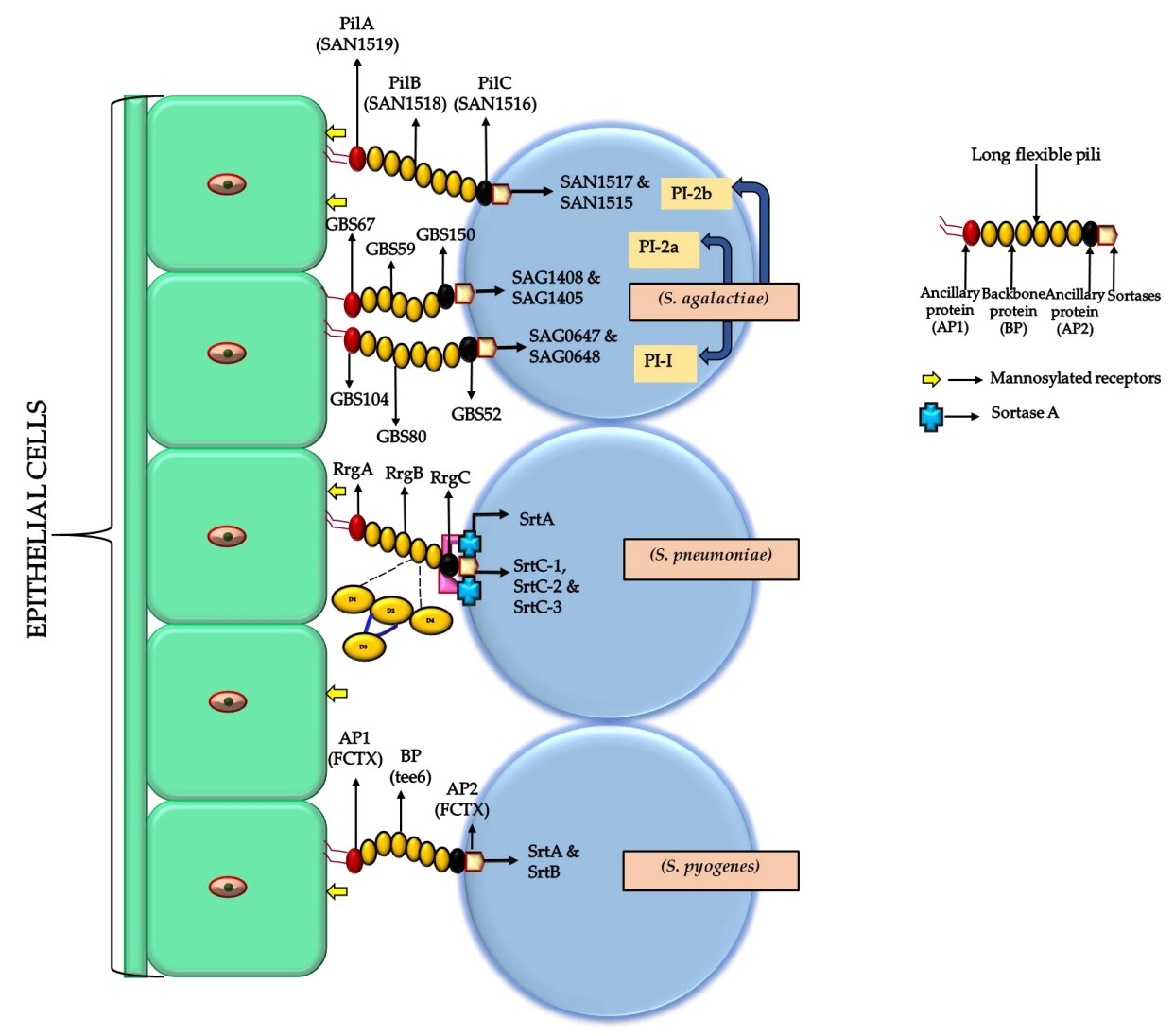

Figure 2. Schematic diagram of general pilus architecture in different streptococci. The blue spheres represent the different bacterial strains, and the green color boxes represent host epithelial cells. The long pili shown in the diagram are formed by three major subunits ancillary protein AP1 (tip protein at the distal end) that attaches to the bacterial surface, backbone protein BP, and ancillary protein AP2, which are assembled by sortases that facilitate adherence with host epithelial cells. AP2 anchors the pilus to the bacterial surface. In S. agalactiae, there are three pilus islands designated as PI-1, PI-2a, and PI-2b. Each pilus island has major protein referred as PI-1 (include GBS104 as AP1, GBS80 as BP, and GBS52 as AP2 with two sortases SAG0647 and SAG0648), in PI-2a (GBS67 as AP1, GBS59 as BP, and GBS150 as AP2 with two sortases SAG1408 and SAG1405), and PI-2b (SAN1519 as AP1, SAN1518 as BP, and SAN1516 as AP2 with two sortases SAN1517 and SAN1515). In S. pneumoniae, pilus subunits are AP1 (RrgA), BP (RrgB), and AP2 (RrgC) with sortases designated as SrtC-1, SrtC-2, and SrtC-3. Here, $\mathrm{RrgC}$ does not depend on pilus-specific sortases for adherence to the cell wall; instead, it binds the preformed pilus to the peptidoglycan by retaining the catalytic activity of SrtA (blue box). RrgB is composed of 4 domains D1 at N-terminus, D2 and D3-positioned laterally, D3 connected to D2 through a loop (dark blue color), and D4 at the C-terminus. In S. pyogenes, the three subunits of pilus include pilus BP (tee6), AP1 and AP2 ( $\left.f_{c t} \mathrm{X}\right)$, and sortases ( $s r t B$ and $\left.s r t A\right)$. The monosyl receptors are present on the surface of epithelial cells and respond to the infection (arrow in yellow color).

Streptococcal pili were first detected in S. agalactiae in 2005 [76]. In this species, three different pilus islands PI-1, PI-2a, and PI-2b have been identified [93,94]. GBS strains carry one or a combination of two pilus islands (PI-2A+ PI-1/PI-2B + PI-1/PI-2a+ PI-2b/PI-2a alone/PI-2b alone). These pilus islands encode classical streptococcal pili that consist of three structural proteins: PilB (the pilin backbone protein), PilA (the pilus associated adhesin at the tip of the pilus), and PilC [45]. GBS mutants with pilB knockouts showed a decreased ability to form biofilms and an impaired interaction with host cells compared to wild-types strains. Systemic infection with GBS lacking pilB resulted in enhanced clearance and reduced mortality in mouse models $[95,96]$. Gene deletion and complementation analysis confirmed the significant correlation between expression of type 2a pili, and the ability to form biofilm in vitro [46]. Detailed genetic studies showed that all mutations leading to a loss of pilus expression 
(deletion of the backbone protein PilB, deletion of sortase-encoding genes, or the deletion of ancillary protein 2 (AP-2 and PilC), which anchors the pilus to the cell wall, prevent biofilm formation. However, some of the GBS strains, not expressing pilus 2a, were also able to form biofilm, which suggests the expression of unknown factors that may compensate for the absence of type 2a pili [46]. All GBS isolates, carry one or two pilus island variant in which PI-2a was the most common among human GBS isolates, while PI-2b was the most common for GBS isolates from animal origin $[46,93,94,97-99]$ (Table 2). Human GBS harboring PI-2b and animal GBS harboring PI-2a presented significantly reduced biofilm production [100]. In conclusion, strong biofilm production seems to be a common characteristic in GBS, and association of the clinical source with the pilus variant may be crucial. Different studies support the findings that GBS biofilm production, similar to the situation in S. pyogenes, is a lineage-specific trait in GBS [98] and is especially important for GBS colonization.

Table 2. Genomic distribution of different pilus island in different Streptococci.

\begin{tabular}{cccccc}
\hline $\begin{array}{c}\text { Streptococci } \\
\text { Species }\end{array}$ & Pilus Operon & $\begin{array}{c}\text { Backbone } \\
\text { Protein }\end{array}$ & $\begin{array}{c}\text { Ancillary } \\
\text { Protein-1 } \\
\text { (Adhesin) }\end{array}$ & $\begin{array}{c}\text { Ancillary } \\
\text { Protein-2 }\end{array}$ & $\begin{array}{c}\text { Gene Encoding for Sortase } \\
\text { Enzyme }\end{array}$ \\
\hline S. agalactiae & PI-1 & $\begin{array}{c}* \text { GBS80 }\left(^{*}\right. \\
\text { mandatory) }\end{array}$ & GBS 104 & GBS 52 & SAG 0647 and SAG 0648 \\
\hline S. agalactiae & PI-2a & GBS 59 & GBS 67 & GBS 150 & SAG 1408 and SAG 1405 \\
\hline S. agalactiae & PI-2b & SAN 1518 & SAN 1519 & SAN 1516 & SAN1517 and SAN 1515 \\
\hline S. pyogenes & fctX operon & Tee6 & fctX & fctX & SrtB and SrtA \\
\hline S. pneumoniae & & RrgB & RrgA & RrgC & SrtC-1, SrtC-2, and SrtC-3 \\
\hline
\end{tabular}

The S. pneumoniae pili are encoded by the $r l r A$ pathogenicity islet, which carries genes for three pilin proteins a major backbone protein $(\operatorname{RrgB})$, a terminal tip protein $(\operatorname{RrgA})$, and a cell wall anchored base ( $\operatorname{RrgC})$ [101] as well as three sortases (SrtC-1, SrtC-2, and SrtC-3) (Table 2). The terminal tip protein (RrgA) mediates bacterial adherence to host ECM proteins [102,103]. The RrgB pilin backbone is composed of four immunoglobulins (Ig)-like domains (D1-D4) [104] with collagen-binding motifs. RrgC does not depend on pilus-specific sortases for attachment to the cell wall; instead, it binds the preformed pilus to the peptidoglycan by retaining the catalytic activity of SrtA [105] (Figure 2). In contrast to other streptococci, in S. pneumoniae, the RrgA tip protein appears to play the most important role during biofilm formation as an isogenic mutant of $\operatorname{rrg} A$ demonstrates impaired biofilm production [106], while mutations of the $\operatorname{rrg} B$ or $\operatorname{rrg} C$ genes did not influence the ability of S. pneumonia to form biofilm.

Pili are also present in oral streptococci belonging to the Streptococcus mitis group, which is closely related to S. pneumoniae. In S. sanguinis, pili are involved in colonization on saliva-coated tooth surfaces and in the human oral cavity. A pili-deficient mutant was incapable of producing a typical three-dimensional layer of biofilm and could not adhere to saliva-coated surfaces [107]. The ancillary protein at the tip of the pilus of S. sanguinis, which was designated PilC, binds to multiple salivary components including salivary alpha amylase. Pilus-mediated binding of $S$. sanguinis to salivary components may help this early colonizer of multispecies biofilms to attach to tooth surfaces and initiate biofilm formation in the oral cavity. In two other species of the S. mitis group, Streptococcus oralis and S. mitis pili were identified, which closely resemble PI-2 pili of S. pneumoniae, however, if there is any involvement in biofilm formation has not been investigated [108]. Surprisingly for one of the most typical streptococcal species in dental multispecies biofilms, Streptococcus mutans, the presence of pili has not been reported.

\subsection{Surface Proteins and Their Role in Biofilm Formation}

Apart from pili, bacterial adhesins play a direct role in the initial step of attachment to host surfaces and thus biofilm formation. For several bacterial surface protein families, their involvement 
in biofilm production has been demonstrated. These include the MSCRAMM family (microbial surface components recognizing adhesive matrix molecules) [109], the AgI/II family [110], the family of collagen-like proteins [111], the choline-binding proteins of S. pneumoniae [112], and the Bap family [31].

In S. pyogenes, fibronectin-binding proteins PrtF1 and PrtF2 of the MSCRAMM family are involved in biofilm formation [113-115], as well as IgG/fibrinogen-binding surface protein Mrp4, and the fibronectin-binding serum opacity factor of S. pyogenes. Another S. pyogenes adhesin Scl1, the streptococcal collagen-like protein 1, binds to fibronectin and has the ability to support biofilm formation as well as facilitate microcolony formation. It is conserved among all S. pyogenes strains investigated so far and is present in many other pathogenic streptococcal species including S. agalactiae, S. pneumoniae, and S. equi [116-118].

The major virulence factor of $S$. pyogenes, the anti-phagocytic M protein, which binds fibrinogen, has also been demonstrated as an important factor in biofilm formation. Biofilm production is strain dependent in S. pyogenes and strongly correlated with the M protein type. An association between $M$ protein expression, surface hydrophobicity, and the ability to form biofilms for certain emm types has been established [119]. Furthermore, the cell wall-anchored adhesin AspA, which belongs to the antigen I/II type family, facilitate biofilm development of S. pyogenes on saliva-coated surfaces [120,121]. A surface protein of $S$. pyogenes with a negative influence on biofilms is the cysteine protease SpeB that promotes the dispersal of biofilms [122].

In S. agalactiae, the adhesive surface proteins and their role in biofilm formation have not been investigated to the same extent as in S. pyogenes. The role of surface proteins for biofilm production was, however, demonstrated through proteinase $\mathrm{K}$ treatment, which inhibited biofilm formation and induced biofilm detachment [48]. The fibrinogen-binding surface protein C (FbsC) is one of the $S$. agalactiae surface proteins investigated in more detail in regard to biofilm formation $[123,124]$. In addition, more recently a member of the Ag I/II family has been identified in S. agalactiae contributing to fibrinogen binding and involved in biofilm production [125].

The role of pneumococcal surface proteins for biofilm formation have been studied primarily in nonencapsulated strains. Among these, the choline-binding proteins (Cbps) of S. pneumoniae, which bind noncovalently to the phosphorocholine residues in the bacterial cell wall [126], have been demonstrated to be involved in biofilm production. Cbps are important for virulence, colonization, and adherence to host cells [112]. They include LytA (the major autolysin), LytB (a glucosaminidase involved in daughter cell separation), and LytC (a lysozyme acting as an autolysin at $30{ }^{\circ} \mathrm{C}$ ), the $\mathrm{CbpA}$ adhesin, the PcpA putative adhesin, and PspA (pneumococcal surface protein A). A direct contribution to biofilm formation in S. pneumoniae has been demonstrated for LytB and LytC [27,127-129].

In the different viridans streptococci species especially the AgI/II and the Bap family of surface proteins play a special role in biofilm production. Common features of the Bap (biofilm-associated proteins) and Bap-related proteins are a high-molecular-weight and a core domain of tandem repeats. They are characterized as cell wall-associated proteins with amyloid behavior, involved in biofilm formation. The AgI/II proteins have been given different names according to the strains or species in which they were identified, such as antigen B, SpaP, Sr, MSL-1, and PAc from S. mutans; Spa A from S. sobrinus; PAa from S. cricetus; and Pas from S. intermedius [130-132].

In $S$. mutans, proteins that are required for the initiation of biofilm formation include SpaP [133]. In addition, protein antigen C (PAc) contributes to the interactions of $S$. mutans cells with fibronectin, collagen type I, and fibrinogen. Independent studies have shown that in S. mutans isogenic Ag I/II-deficient mutants, the initial adhesion to salivary films was reduced [134,135]. It was found that wapA, SMU_63c, forms amyloid like fibrils but individual mutants of P1 (which originally identified as AgI/II or PAc), wapA or 63c, did not reduce biofilm formation in S. mutans. P1 forms a fibril-like structures contributing to functional amyloid formation during biofilm development. However, double and triple mutants of these genes show reduced biofilm formation [136]. As mentioned before, the glucans of the extracellular matrix play a critical role during attachment and accumulation of 
S. mutans to the host niche. Binding of $S$. mutans to these glucans is facilitated by four different cell surface-associated GBPs (glucan-binding proteins), namely, GbpA, GbpB, GbpC, and GbpD [137].

In regard to Streptococcus parasanguis the fimbria-associated serine-rich repeat adhesin BapA1 and Fap1 (fimbriae-associated protein 1), a high-molecular-weight glycoprotein, which is essential for assembly of fimbriae, are both critical for biofilm formation [138]. They show a similar biofilm-deficient phenotype, but function independently. Bacterial autoaggregation during biofilm formation is mediated through the N-terminal region of BapA1, by BapA1-BapA1 interactions. Deletion of the 3' portions of bapA1 leads to a loss of bacterial autoaggregation and reduces biofilms development [138].

In summary, numerous different cell surface proteins with the ability to bind extracellular matrix components or to mediate adhesion to host cells are also involved in biofilm production, reflecting the importance of initial attachment to host structures for the successful establishment of a streptococcal biofilm.

\section{Regulation}

The formation of biofilms is a complex multistep process that needs proper control of gene expression patterns. Thus, sensing environmental stimuli and adaptation of the gene expression is crucial and can only be realized by complex regulatory networks (Figure 3A,B).

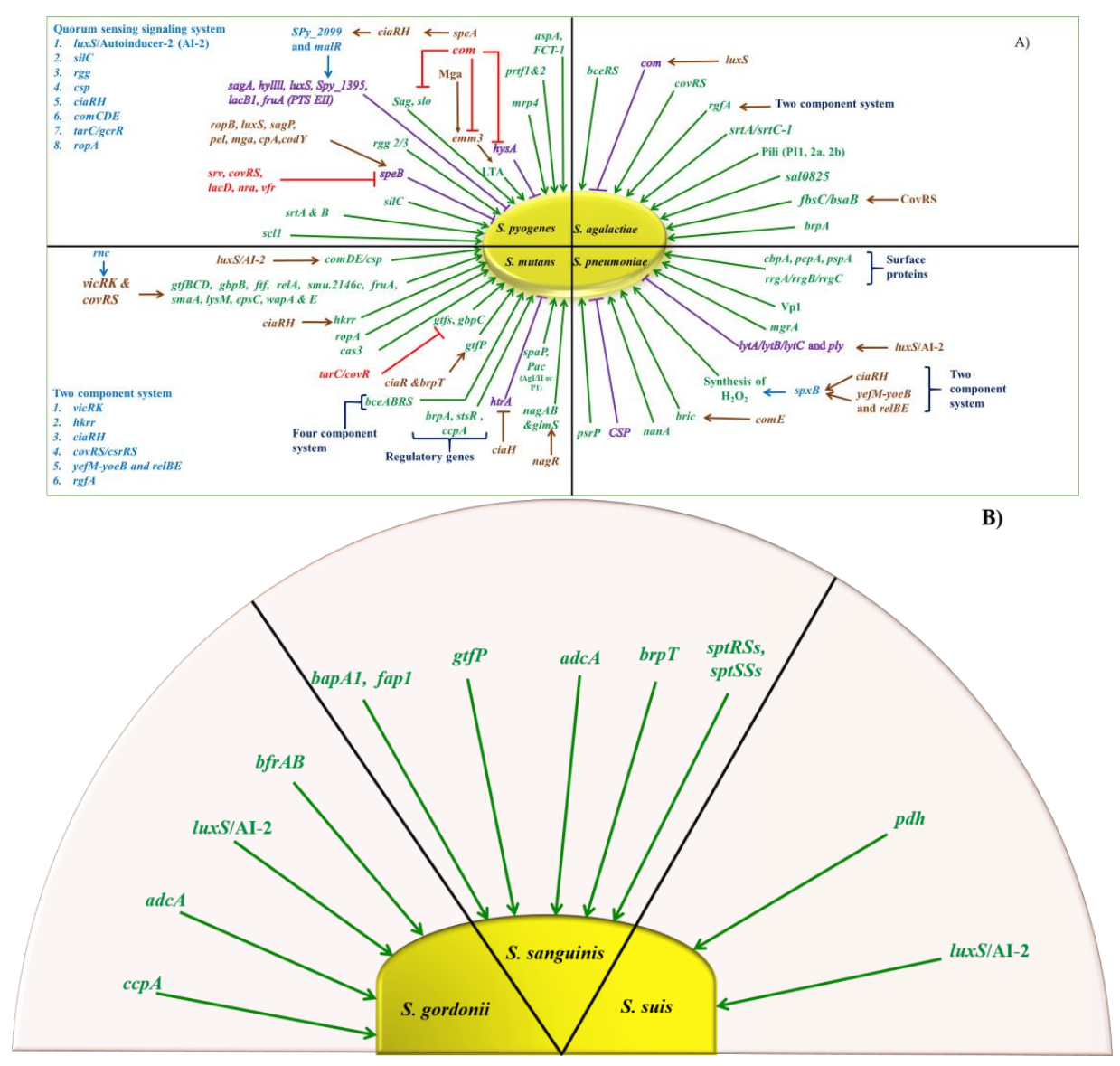

Figure 3. (A) Regulation of biofilm in different streptococcal species at the genetic level. The figure describes the gene regulation system in S. pyogenes, $S$, mutans, S. agalactiae, and S. pneumoniae for direct effect on biofilm inhibition (shown in purple), induction (shown in green), negative regulators (shown in red), and positive regulators (shown in brown and blue). (B) Involvement of virulence genes in the regulation of biofilm in different species of the Streptococcus mitis group and S. suis. The represented genes of S. gordonii, S. sanguinis, and S. suis are involved in the positive regulation of biofilm formation and thus directly involved in increasing the biomass of forccpamed biofilm. 


\subsection{GAS}

The transition of a planktonic to a sessile biofilm lifestyle is associated with global changes in gene expression, which affects about $25 \%$ of all GAS genes (Table 3) [139]. During biofilm growth, classical virulence genes, typically involved in invasive disease, like the streptolysins ( $\operatorname{sag} A$ and $s l o$ ), the hyaluronic acid capsule biosynthesis (has $A$ ), the M-protein, and the streptococcal pyrogenic exotoxin B (speB) are downregulated, whereas competence-associated genes are upregulated (Table 3) [140]. The observed downregulation of speB during biofilm growth plays an important role in the biogenesis of the biofilm in GAS as dispersal of the biofilm seems to be speB dependent and the absence of speB is required for biofilm growth [141]. The extracellular cysteine protease SpeB appears to be responsible for the degradation of extracellular biofilm proteins [142]. Multiple regulatory pathways are involved in the transcriptional control of speB [143] including seven activators (ccpA, ropB, $m g a$, pel, $\operatorname{cod} Y$, sagP, and $l u x S$ ) and five repressors (covRS, svr, lacD.1, nra, and vfr) (Figure 3A and Table 3). Some of these regulatory pathways (CovRS, Mga, and LuxS) are indirectly linked to biofilm formation via the regulation of other effector genes.

The two-component system CovRS influences the expression of around $15 \%$ of chromosomal genes in GAS and is involved in the regulation of important virulence factors including the capsule, surface adhesins, and extracellular enzymes $[144,145]$. As a negative regulator of the capsule biosynthesis operon HasABC and as the capsule was shown to be involved in biofilm maturation [141], a mutation in CovRS would be expected to result in increased biofilm formation. Instead, CovS mutants of M2, M18, and M49 strains showed a reduced biofilm formation although the capsule production was increased [146]. A strain-dependent alteration of the biofilm production was observed in M6 strains, $[139,146]$ indicating that the influence of CovRS on the biofilm regulation is serotype and even strain dependent [39]. Mga, the major stand-alone positive regulator of emm and emm-like genes, influences biofilm production besides speB regulation (Table 3) [147-149]. Neither a mga deletion strain nor an emm deletion strain retained their biofilm formation capacity potentially because of the loss of autoaggregation $[139,150]$. Besides speB regulation, the LuxS/Autoinducer-2 regulatory system is involved in the control of streptolysin S, emm, and capsule expression [151,152], with the latter two factors known to influence biofilm formation. Thus, the LuxS/AI-2 system could be involved in biofilm regulation in GAS, but no difference between wild-type and the corresponding luxS-deficient strains for the initial step of biofilm formation could be observed (Table 3) [153].

Two other quorum sensing systems, SilC and Rgg2/3, were also described as being involved in biofilm regulation in GAS as a silC mutant in $e m m 14$ and $e m m 18$ strains exhibited an altered biofilm structure [41] and the stimulation of the Rgg2/3 pathway resulted in increased biofilm biogenesis (Table 3) [154]. However, as the sil system is only poorly conserved and not present in the majority of clinical GAS isolates [42] and as the effector genes of the Rgg2/3 system that mediate the biofilm effect are not known yet, the contribution of these systems to biofilm regulation in GAS still needs to be further elucidated.

\subsection{GBS}

Although multiple QS (Quorum Sensing) systems are described in the regulation of adhesion and colonization in GBS, for many of these systems, no role in the regulation of biofilm was demonstrated $[155,156]$. An exception is CovRS, the TCS, which regulates adhesive proteins like $\mathrm{BsaB} / \mathrm{FbsC}$. covRS-mutant bacteria show an increased adherence to host cells and an increased formation of biofilm-like structures $[123,124,157]$. BceRS is also among the TCS involved in the biofilm regulation of GBS. A mutant of the response regulator $b c e R$ showed a reduced mortality in a murine infection model and a reduced biofilm formation potentially due to a compromised oxidative stress response [158]. Another two-component regulatory system, RgfA/C, regulates fibrinogen binding $[159,160]$ and may thus be involved in biofilm formation (Table 3). For veterinary S. agalactiae strains, the quorum sensing signaling system (LuxS) has been shown to participate in biofilm formation [72]. 
Recently, a novel biofilm regulatory protein A (BrpA) was characterized in GBS due to the strong reduction in biofilm biomass in a brpA-mutant strain [161]. Although the authors investigated the transcriptome of the mutant, a conclusive reason for the loss of biofilm formation could not be identified so far as prominent surface structures like pilus type 2a and antigens I/II that were involved in GBS biofilm formation $[46,125]$ were still present in the brpA mutant (Table 3).

\subsection{S. pneumoniae}

S. pneumoniae colonization and disease is often linked to biofilm formation. However, the regulation of the initial steps of biofilm formation and maturation are only partly understood (Table 3). Here, QS systems, the LuxS/Autoinducer-2, and the competence system are involved in the biofilm regulation in S. pneumonia. Although the Lux QS system seems to be important during early steps of biofilm formation [162], the competence system seems to be implicated in early and later stages dependent on the biofilm model $[163,164]$.

The link between the competence system and biofilm formation was illusive till recently as Aggarwal and colleagues described BriC (biofilm-regulating peptide induced by competence), a peptide under transcriptional control of ComE that leads to increased biofilm biomass at later stages of the biofilm development [165]. Another small secreted peptide, VP1, was discovered in the same secretome study that identified BriC [166] and a pneumococcal mutant of VP1 formed less biofilm. The reduced biofilm formation could be restored by external VP1 addition probably due to a membrane-bound receptor recognizing VP1 at the cell surface [166].

An orthologue of the GAS Mga regulator in S. pneumoniae, the virulence regulator MgrA, was also described in relation to biofilm formation showing increased expression in biofilm compared to planktonic growth [23]. Additionally, $m g r A$ is an important factor during nasopharyngeal colonization and pneumonia [167], two bacterial lifestyles associated with biofilm formation.

\subsection{Viridans Streptococcus}

As the etiological agent of caries, S. mutans is the best investigated member of the viridans streptococci concerning the regulation of biofilm formation (Table 3). Thus, multiple TCS systems are described as part of a complex regulatory network including VicRK, CiaRH, and CovRS. Reduced biofilm biomass and viable cell numbers were observed in vic-mutant cells [168], and a direct regulation of glycosyltransferases and glucan-binding proteins was demonstrated for VicR highlighting the role of this TCS for the adherence and early steps of biofilm growth in S. mutans [169-171]. Biofilm formation was also reduced in a ciaH mutant probably due to increased expression of the protease HtrA [172-175]. An orthologue of the prominent CovR regulator of GAS and GBS is encoded in S. mutans and was initially designated TarC [176]. Usually, CovR is the response regulator of a TCS including a histidine kinase, in $S$. mutans, however, $\operatorname{cov} R$ is an orphan gene as no homologue to CovS could be detected. CovR represses the glycosyltransferases $g t f B, g t f C$, and $g t f D$ and the glucan-binding protein $g b p C$, factors known to influence biofilm formation, and a $\operatorname{cov} R$ mutation results in an altered biofilm architecture (Table 3) [176,177].

Two quorum sensing systems were described in relation to biofilm regulation in S. mutans. The bacteriocin controlling system ComDE/CSP is involved in the programmed cell death and persister cell formation during biofilm growth, and the LuxS/Autoinducer-2 system participates in the regulation of the early steps of biofilm formation [178-181].

A central role in the regulation of biofilm formation in S. mutans is realized by BrpA, an orthologue of GBS BrpA. The expression of more than 200 genes is altered in a brpA mutant including genes involved in stress tolerance, adherence, and cell wall biogenesis resulting in a profound biofilm-formation defect [182-184]. Another regulatory protein the peptidyl-prolyl isomerase (RopA) plays a substantial role in biofilm formation with or without saliva and sucrose [185]. Transcriptional regulator BrpT negatively regulates the $g t f P$ expression as deletion of $b r p T$ promotes the expression of $g t f P$ and displays increased biofilm formation ability. 
A link between exopolysaccharide synthesis and biofilm formation was demonstrated by the characterization of $r n c$. A-mutant strain showed an altered biofilm formation and reduced bacterial adhesion. Additionally, $r n c$ affects the expression of the TCS VicRK, which itself is involved in biofilm regulation $[186,187]$. Two additional regulators were reported to be involved in biofilm control in $S$. mutans. The StsR protein, a GntR transcription factor, seems to positively regulate biofilm formation and EPS production, although the effect was not to pronounced and the mutant of stsR showed a growth delay, which could be responsible for the observed phenotypes [188]. The other factor NagR was demonstrated to regulate the expression of $g \operatorname{lm} S$ and $n a g A B$, which are known to be involved in biofilm formation $[189,190]$. However, a nagR-mutant strain was so far not tested for biofilm formation; thus, it remains elusive if the regulation of NagR directly affects biofilm growth.

Only little is known about other members of the viridans streptococci concerning biofilm regulation (Table 3). The LuxS/Autoinducer-2 QS system is described in S. anginosus and S. gordonii, with the difference that a $l u x S$ mutant in $S$. anginosus seems to be almost deficient in biofilm formation, whereas a luxS mutant in S. gordonii and in S. suis formed an altered microcolony structure within the early biofilm [68,191]. Additionally, CcpA, the catabolite control protein A, was described as important for the biofilm formation of $S$. gordonii and S. mutans, as a $c c p A$-mutant strain showed a reduced biofilm biomass under various growth conditions [192]. In S. sanguinis, the regulation of the glycosyltransferase $g t f P$ was described in two independent mutant strains, ciaR and $b r p T$, both demonstrating positive association of $g t f P$ expression and biofilm formation $[62,193]$. In $S$. gordonii, TCS system named "BfrAB," which encodes two $\mathrm{ABC}$ transporters and a CAAX amino-terminal protease family protein, promotes biofilm development [72].

Sugar metabolism enzyme was identified in S. suis, and the gene involve in the process is said to be as pyruvate dehydrogenase $(p d h)$, which acts as temperature stress, salt stress, and oxidative stress controller and involves in adhesion, biofilm formation, and antiphagocytic activity [194].

In S. sanguinis, SptRSs and SptSSs are the TCS systems that coordinate cell wall homeostasis and are involved in $\mathrm{H}_{2} \mathrm{O}_{2}$ production and competence [195]. Another quorum sensing system is homoserine kinase $(t h r B)$, which is involved in threonine biosynthesis. Metal $(\mathrm{Zn})$-binding permease ( $a d c A)$ shows implication in biofilm formation by S. gordonii Challis and S. sanguinis [196]. There are three genes, which are identified and found to be responsible for de novo pyrimidine biosynthesis, and these are orotate phospho-ribosyl-transferase (pyrE), phospho-ribosyl-formyl-glycin-amidine synthase ( $p u r L$ ), and adenylosuccinate lyase (purB) (Figure 3B and Table 3) [196].

Table 3. List of different genes present in Streptococcal species that are involved in biofilm formation and act as adhesins, virulence factors, or regulators.

\begin{tabular}{|c|c|c|c|c|}
\hline $\begin{array}{l}\text { Virulence } \\
\text { Factors }\end{array}$ & Genes & Function & $\begin{array}{l}\text { Streptococci } \\
\text { Species }\end{array}$ & Reference \\
\hline \multirow{6}{*}{$\begin{array}{l}\text { Quorum sensing } \\
\text { system }\end{array}$} & \multirow[b]{2}{*}{$\operatorname{luxS}$} & $\begin{array}{l}\text { Key regulator of early biofilm } \\
\text { formation }\end{array}$ & S. gordonii & [61] \\
\hline & & $\begin{array}{c}\text { Involvement in virulence, } \\
\text { competence, biofilm formation, acid } \\
\text { and oxidative stress tolerance, and } \\
\text { carbohydrate metabolism }\end{array}$ & S. agalactiae & [72] \\
\hline & & $\begin{array}{l}\text { Regulation of lyt } A \text { and early biofilm } \\
\text { formation }\end{array}$ & S. pneumoniae & {$[162,197]$} \\
\hline & & Regulatory role in biofilm formation & S. mutans & [178] \\
\hline & & $\begin{array}{l}\text { Key regulator of early biofilm } \\
\text { formation }\end{array}$ & S. suis & {$[198,199]$} \\
\hline & $\begin{array}{l}\text { Streptococcal invasion } \\
\text { locus (silC) }\end{array}$ & $\begin{array}{l}\text { Regulator affecting biofilm } \\
\text { architecture and density }\end{array}$ & S. pyogenes & [41] \\
\hline
\end{tabular}


Table 3. Cont.

\begin{tabular}{|c|c|c|c|c|}
\hline $\begin{array}{l}\text { Virulence } \\
\text { Factors }\end{array}$ & Genes & Function & $\begin{array}{l}\text { Streptococci } \\
\text { Species }\end{array}$ & Reference \\
\hline & $\begin{array}{l}\text { Regulatory gene of } \\
\text { glucosyltransferase } \\
\qquad(r g g)\end{array}$ & $\begin{array}{c}\text { Universal streptococcal regulator } \\
\text { involved in intraspecies } \\
\text { communication, increased biogenesis } \\
\text { of biofilms by } r g g 2 \mathrm{rgg} 3\end{array}$ & S. pyogenes & [142] \\
\hline & $\begin{array}{l}\text { Competence-stimulating } \\
\text { peptide }(C S P)\end{array}$ & $\begin{array}{l}\text { Competence development, involved } \\
\text { in later stages of biofilm production }\end{array}$ & S. pneumoniae & {$[23,200]$} \\
\hline & $\operatorname{com} C D E$ & $\begin{array}{l}\text { Regulation of competence through } \\
\text { production of competence-stimulating } \\
\text { peptide (CSP) }\end{array}$ & S. mutans & {$[178,181]$} \\
\hline \multirow{10}{*}{$\begin{array}{l}\text { Two-component } \\
\text { signaling system }\end{array}$} & $b f r A B$ & $\begin{array}{l}\text { Regulator involved in the maturation } \\
\text { of multispecies biofilms }\end{array}$ & S. gordonii & [72] \\
\hline & bceRS & $\begin{array}{l}\text { Control of oxidative stress response } \\
\text { and biofilm production }\end{array}$ & S. agalactiae & [158] \\
\hline & Histidine kinase $(\mathrm{ciaH})$ & $\begin{array}{l}\text { Regulatory role in biofilm formation, } \\
\text { acid tolerance, and genetic } \\
\text { competence }\end{array}$ & S. mutans & [172] \\
\hline & vicR/K system (vicK) & $\begin{array}{l}\text { Modulates the expression of several } \\
\text { genes such as } g t f B C D, g b p B, f t f, \text { wap E, } \\
\text { smaA, } S M U .2146 c, l y s M \text {, and } e p s C \text { that } \\
\text { affect the synthesis of EPS and biofilm } \\
\text { formation }\end{array}$ & S. mutans & {$[169,201,202]$} \\
\hline & $\operatorname{ciaR} / H$ & Control of the competence operon & S. pneumoniae & [203] \\
\hline & yefM-yoeB and relBE & $\begin{array}{l}\text { Control of resistance towards } \\
\text { oxidative stress and involvement in } \\
\text { biofilm formation }\end{array}$ & S. pneumoniae & [204] \\
\hline & $\operatorname{rgf} A$ & Control of adherence to fibrinogen & \multirow{2}{*}{ S. agalactiae } & {$[159,160]$} \\
\hline & $\operatorname{cov} R / S$ & $\begin{array}{l}\text { Major virulence and adherence } \\
\text { regulator }\end{array}$ & & {$[123,124,157]$} \\
\hline & $\begin{array}{l}\text { Histidine kinase }(h k 11) \\
\text { and response regulator } \\
(r r 11)\end{array}$ & $\begin{array}{l}\text { Control of biofilm formation and acid } \\
\text { resistance }\end{array}$ & S. mutans & [205] \\
\hline & sptRSs and sptSSs & $\begin{array}{c}\text { Coordination of cell wall homeostasis, } \\
\text { involved in } \mathrm{H}_{2} \mathrm{O}_{2} \text { production, and } \\
\text { competence }\end{array}$ & S. sanguinis & [195] \\
\hline $\begin{array}{l}\text { Four-component } \\
\text { system }\end{array}$ & $b c e A, b c e B, b c e R$, or $b c e S$ & $\begin{array}{l}\text { Regulation of sensitivity towards } \\
\text { antimicrobial peptides and } \\
\text { requirement for biofilm formation }\end{array}$ & S. mutans & [206] \\
\hline $\begin{array}{l}\text { CRISPR/Cas } \\
\text { systems }\end{array}$ & cas3 gene & $\begin{array}{l}\text { Bacterial immunity, effect on biofilm } \\
\text { formation, and fluoride sensitivity }\end{array}$ & S. mutans & [202] \\
\hline $\begin{array}{l}\text { Extracellular } \\
\text { enzyme }\end{array}$ & $\begin{array}{l}\text { Glucosyltransferases } \\
(g t f B, g t f C \text {, and } g t f D) \\
\text { and } \\
\text { fructosyltransferases } \\
\qquad(f t f s)\end{array}$ & $\begin{array}{l}\text { Carbohydrate metabolism for the } \\
\text { generation of exopolysaccharide }\end{array}$ & S. mutans & [207] \\
\hline $\begin{array}{c}\text { Sugar } \\
\text { metabolism } \\
\text { enzyme }\end{array}$ & $\begin{array}{c}\text { Pyruvate } \\
\text { dehydrogenase }(p d h)\end{array}$ & $\begin{array}{l}\text { Control of environmental stress and } \\
\text { promotion of biofilm formation }\end{array}$ & S. suis & [194] \\
\hline Glucan binding & $\begin{array}{l}\text { Glucan-binding } \\
\text { protein }(g b p A, g b p B, \\
\text { and } g b p C)\end{array}$ & $\begin{array}{l}\text { Adhesion and promotion of biofilm } \\
\text { formation }\end{array}$ & S. mutans & {$[208,209]$} \\
\hline Amyloid proteins & $\begin{array}{l}\text { Wall-associated protein } \\
\quad(\text { wap } A \text { and wapE) }\end{array}$ & Production of extracellular matrix & S. mutans & [136] \\
\hline
\end{tabular}


Table 3. Cont.

\begin{tabular}{|c|c|c|c|c|}
\hline $\begin{array}{l}\text { Virulence } \\
\text { Factors }\end{array}$ & Genes & Function & $\begin{array}{l}\text { Streptococci } \\
\text { Species }\end{array}$ & Reference \\
\hline \multirow{4}{*}{$\begin{array}{l}\text { Regulatory } \\
\text { proteins }\end{array}$} & \multirow{2}{*}{$\begin{array}{l}\text { Biofilm regulatory } \\
\text { protein }(b r p A)\end{array}$} & $\begin{array}{l}\text { Regulation of acid and oxidative } \\
\text { stress tolerance and biofilm formation }\end{array}$ & S. mutans & {$[182,205,210]$} \\
\hline & & Virulence regulator stress tolerance & S. agalactiae & [211] \\
\hline & $\begin{array}{c}\text { Sugar Transporter } \\
\text { Systems Regulator } \\
(\text { stsR) }\end{array}$ & $\begin{array}{l}\text { Formation of biofilm and production } \\
\text { of extracellular polysaccharides (EPS) } \\
\text { at early stage }\end{array}$ & S. mutans & [188] \\
\hline & $\begin{array}{l}\text { Catabolite control } \\
\text { protein }(c c p A)\end{array}$ & $\begin{array}{l}\text { Global transcriptional regulator of } \\
\text { carbon catabolite repression, } \\
\text { involvement in biofilm formation }\end{array}$ & S. mutans & [210] \\
\hline Surface protease & Serine protease $(h t r A)$ & $\begin{array}{l}\text { Processing and maturation of } \\
\text { extracellular proteins } \\
\text { including surface associated } \\
\text { glycolytic enzymes (GbpB, GtfB, and } \\
\text { FTF) contributing to biofilm formation }\end{array}$ & S. mutans & [174] \\
\hline \multirow[t]{4}{*}{$\begin{array}{l}\text { Surface-associated } \\
\text { proteins }\end{array}$} & $\begin{array}{l}\text { Fimbria-associated } \\
\text { serine-rich repeat } \\
\text { adhesin (fap1) } \\
\text { and (bapA1) }\end{array}$ & $\begin{array}{l}\text { Adhesins with important role in } \\
\text { biofilm initiation }\end{array}$ & S. sanguinis & [212] \\
\hline & $\begin{array}{l}\text { Choline-binding } \\
\text { protein adhesin }(c b p A), \\
\text { putative adhesin } \\
(p c p A), \text { and } \\
\text { pneumococcal surface } \\
\text { protein } \mathrm{A}(p s p A)\end{array}$ & $\begin{array}{l}\text { Adhesins binding to the teichoic acids } \\
\text { of the cell wall, involvement in } \\
\text { immune evasion, and promotion of } \\
\text { biofilm formation }\end{array}$ & S. pneumoniae & {$[27,53]$} \\
\hline & $\begin{array}{l}\text { Pneumococcal } \\
\text { serine-rich repeat } \\
\text { protein }(p s r P)\end{array}$ & $\begin{array}{l}\text { Adhesion to host cells and mature } \\
\text { biofilm formation }\end{array}$ & S. pneumoniae & [213] \\
\hline & $\begin{array}{c}\text { Pyruvate oxidase } \\
(\operatorname{sp} x B)\end{array}$ & Responsible for the synthesis of $\mathrm{H}_{2} \mathrm{O}_{2}$ & & {$[53,214]$} \\
\hline \multirow{3}{*}{ Pili/fimbriae } & $\begin{array}{l}\text { Genomic island (PI-1, } \\
-2 \mathrm{a},-2 \mathrm{~b}) . \text { All islands } \\
\text { contain } 3 \text { genes } \\
\text { encoding pilus } \\
\text { component }\end{array}$ & $\begin{array}{l}\text { Pilus assembly and creation of } \\
\text { biofilms }\end{array}$ & S. agalactiae & [93-95] \\
\hline & $\operatorname{rrg} A, r r g B$, and $r r g C$ & $\begin{array}{l}\text { Pilus subunits and involvement in } \\
\text { biofilm formation }\end{array}$ & S. pneumoniae & [106] \\
\hline & $\begin{array}{l}\text { FCT-1 region }(f c t X, \\
\text { srt } B, \text { and tee } 6)\end{array}$ & Pili and biofilm formation & S. pyogenes & [84] \\
\hline \multirow{2}{*}{ Adhesin } & $\begin{array}{c}\text { Bacterial surface } \\
\text { adhesin of GBS (BsaB) } \\
\text { (sal0825) }\end{array}$ & $\begin{array}{l}\text { Attachment of GBS to epithelial cells, } \\
\text { extracellular matrix and promotion of } \\
\text { biofilm production }\end{array}$ & S. agalactiae & [124] \\
\hline & $\begin{array}{l}\text { Fibrinogen-binding } \\
\quad \text { protein }(f b s C)\end{array}$ & $\begin{array}{l}\text { Fibrinogen binding, promotion of } \\
\text { invasion of epithelial and endothelial } \\
\text { barriers, biofilm formation }\end{array}$ & S. agalactiae & [123] \\
\hline Antigen & Neuraminidase (nanA) & $\begin{array}{l}\text { Release of sialic acid residues, } \\
\text { modification of immune defense } \\
\text { proteins, promotion of colonization } \\
\text { and biofilm formation }\end{array}$ & S. pneumoniae & [215] \\
\hline Autolysin & $\begin{array}{c}\text { lyt } A \text { (amidase), } \\
\text { lytB (glucosaminidase), } \\
\text { and } \\
\text { lytC (lysozyme) }\end{array}$ & $\begin{array}{l}\text { Cell separation, autolysis and } \\
\text { promotion of biofilm dispersion }\end{array}$ & S. pneumoniae & {$[27,216]$} \\
\hline
\end{tabular}


Table 3. Cont.

\begin{tabular}{|c|c|c|c|c|}
\hline $\begin{array}{l}\text { Virulence } \\
\text { Factors }\end{array}$ & Genes & Function & $\begin{array}{l}\text { Streptococci } \\
\text { Species }\end{array}$ & Reference \\
\hline M-protein & emm & $\begin{array}{l}\text { Key virulence factor, antiphagocytic, } \\
\text { immune evasion, adhesin, and } \\
\text { contribution to biofilm formation }\end{array}$ & S. pyogenes & {$[38,119,142]$} \\
\hline $\begin{array}{l}\text { Hyaluronic acid } \\
\text { capsule }\end{array}$ & $\begin{array}{l}\text { Hyaluronate synthase } \\
\text { (has } A)\end{array}$ & $\begin{array}{l}\text { Escape of phagocytosis involvement } \\
\text { in biofilm maturation }\end{array}$ & S. pyogenes & {$[38,139]$} \\
\hline \multirow{2}{*}{ Sorting signal } & $\begin{array}{l}\text { Sortase A }(\operatorname{srt} A) \text {, } \\
\text { sortase C }(\operatorname{srtC}-1)\end{array}$ & $\begin{array}{c}\text { Pilus polymerization and cell wall } \\
\text { attachment }\end{array}$ & S. agalactiae & {$[43,46]$} \\
\hline & Sortase (srt $A$ and $s r t A$ ) & $\begin{array}{l}\text { Pili assemblance and biofilm } \\
\text { production }\end{array}$ & S. pyogenes & [39] \\
\hline $\begin{array}{l}\text { Transcriptional } \\
\text { regulator }\end{array}$ & $\begin{array}{l}\text { Streptococcal regulator } \\
\text { of virulence }(\mathrm{srv})\end{array}$ & $\begin{array}{c}\text { Transcriptional regulator of virulence } \\
\text { and contribution to biofilm dispersal } \\
\text { by degrading SpeB }\end{array}$ & S. pyogenes & {$[122,142]$} \\
\hline $\begin{array}{l}\text { Streptococcal } \\
\text { antigen I/II } \\
\text { (AgII/II) family } \\
\text { polypeptides }\end{array}$ & $\begin{array}{l}\text { Group A Streptococcus } \\
\text { protein A }(a s p A)\end{array}$ & $\begin{array}{l}\text { Adhesion to human salivary } \\
\text { glycoproteins and facilitation of } \\
\text { colonization to develop biofilm }\end{array}$ & S. pyogenes & {$[38,39]$} \\
\hline $\begin{array}{l}\text { Collagen-like } \\
\text { protein }\end{array}$ & $\begin{array}{c}\text { Streptococcal } \\
\text { collagen-like gene-1 } \\
(s c l-1)\end{array}$ & Cell surface adhesin & S. pyogenes & [142] \\
\hline $\begin{array}{l}\text { MSCRAMM } \\
\text { family proteins }\end{array}$ & $\begin{array}{l}\text { Fibronectin-binding } \\
\text { protein } \mathrm{F}(p r t F 1 \text { and } \\
\text { prtF2) and } m r p 4\end{array}$ & Adherence to host epithelial cells & S. pyogenes & {$[38,39,111]$} \\
\hline \multirow[b]{2}{*}{ Exotoxin } & (speA) & $\begin{array}{l}\text { Superantigen involved in the } \\
\text { dispersal of biofilm }\end{array}$ & \multirow[t]{2}{*}{ S. pyogenes } & \multirow[t]{2}{*}[122,217]{} \\
\hline & $\begin{array}{l}\text { Cysteine protease } \\
\text { (speB) }\end{array}$ & $\begin{array}{l}\text { Cleavage of streptococcal cell surface } \\
\text { virulence factors such as M protein, } \\
\text { protein } \mathrm{F} \text {, and C5a peptidase. } \\
\text { Dispersal of biofilm }\end{array}$ & & \\
\hline
\end{tabular}

\section{Therapeutic Antibiofilm Approaches}

The treatment of bacteria growing in biofilms is challenging due to the increased tolerance towards antibiotics and their protection against the host immune system. Identification of agents that interfere with biofilm formation may increase the effectiveness of antimicrobials and allow access of host defenses, which may then resolve the infection. To prevent biofilm formation, innovative approaches aim at specific therapeutic targets. These may include biofilm regulation, degradation of the extracellular matrix, and the targeted delivery of antimicrobial peptides and other antibiofilm agents.

\subsection{Quorum Sensing Systems}

Biofilm formation shows a close biological connection with the quorum sensing (QS) systems found in many streptococci. Several different ways can be used to interrupt QS-associated cell communication system including: competitive inhibition of signaling molecules, compounds with signaling molecules binding capacity, and degradation of the chemical structures of signaling molecules. Interestingly signaling molecules like the competence-stimulating peptide of $S$. mutans may at higher concentrations cause bacterial self-destruction and thus interfere with biofilms [218]. KBI-3221, an analog of the competence-stimulating peptides of various Streptococci, reduces biofilm formation in several species [219]. In another study, the QS mechanism interfering compound 5-hydroxymethylfurfural was shown to inhibit biofilm formation in different streptococcal species [220]. These studies highlight that an interference with quorum sensing regulation appears a promising antibiofilm strategy, which may also represent a more general approach to interfere with host microbe interactions [221]. 


\subsection{Target Extracellular Polysaccharide (EPS) Matrix}

Biofilm matrix components, such as polysaccharides, proteins, and eDNA, are crucial for providing resistance against antimicrobials, the immune system, and environmental stressors [222,223]. The inhibition of biofilm formation can thus be achieved by matrix degrading enzymes that can induce biofilm dispersion, biofilm detachment, and reduction in cell aggregation [224]. While different types of compounds have been shown to degrade EPS in E. coli, P. aeruginosa, and staphylococci [225-227], a few studies exist on streptococci. DNase I as well as different proteases have been shown to degrade biofilm matrices in streptococci $[29,228,229]$, despite potential toxicity to the host they may be useful in developing novel therapeutic approaches [230]. In 2015, Ren et al. reported a more specific approach to target the EPS of oral multispecies biofilm [231]. They identified a compound termed $5 \mathrm{H} 6$ as an inhibitor of glucosyltransferases, a key contributor to the EPS of S. mutans, and they could show the effect of $5 \mathrm{H} 6$ on preventing caries development in an in vivo rat model.

\subsection{Antimicrobial Peptides (AMPs)}

Most antimicrobial peptides are small cationic and amphipathic peptides that are part of the host innate immune system. AMPs have been shown to interfere with various stages of biofilm formation independent from their ability to kill bacterial cells [232]. Some of the most prominent examples of AMPs showing biofilm preventive activity include the human cathelicidin peptide LL-37 (derivative of mucosal epithelial cells and several cells of the immune system), Lactoferrin, Oritavancin (semisynthetic lipoglycopeptide), DJK-5, and DJK-6 (synthetic analog of active antibiofilm peptides), DD13-RIP (chimeric compound), and (IDR-)1018 (bactenecin derivative) [233,234]. In regard to streptococci Chrysophsin-1, IDR-1018 and pleurocidin have been shown to exhibit antibiofilm activity [218,235-237]. The AMP C16G2 may even selectively remove $S$. mutans from multispecies oral biofilms and shift the microbial community towards beneficial streptococcal species [238]. An attractive approach is to strengthen the antibiofilm activity of AMPs by targeted delivery. Specificity, e.g., can be increased by conjugation to a pathogen-specific siderophore, packaged within a phage delivery system [239]. Furthermore the combination of an AMP with conventional antibiotics can strengthen the antimicrobial activity, at sub-MBIC (minimal biofilm inhibition concentration) levels, IDR-1018, e.g., causes a 64-fold decrease in the respective MBIC of several antibiotics [239]. In summary, coadministration of AMPs with antibiotics or other antimicrobial strategies may offer an effective way to combat streptococcal biofilms.

\subsection{Bacteriocins}

Bacteriocins are antimicrobial peptides, which are produced by bacteria to kill closely related bacteria. While they may have similar antibiofilm properties as eukaryotic AMPs, these have not been investigated to the same extent. Nisin has been shown to interfere with biofilms in several bacterial species including enterococci $[240,241]$, there are, however, conflicting reports about the activity of nisin on S. mutans biofilms [242,243]. In summary the potential antibiofilm properties of bacteriocins have not been sufficiently explored for streptococci.

\subsection{Nanodrug Delivery System}

Nanoparticles are an emerging technology used for drug delivery and selective targeting of pathogenic bacteria with the ability to penetrate biofilms [230]. Liposomes, e.g., can carry more than one drug by coencapsulation and can also be functionalized by linking biomolecules such as peptides or polymers to increase target specificity and to provide a triggered release [244]. Inorganic nanoparticles such as iron oxide $\left(\mathrm{Fe}_{3} \mathrm{O}_{4}\right)$ with a peroxidase-like function catalyzes hydrogen peroxide $\left(\mathrm{H}_{2} \mathrm{O}_{2}\right)$ showing potent effects against $S$. mutans oral biofilms in vivo [245]. Several other studies using metallic nanoparticles underline their potential as antibiofilm strategies [246-249]. Overall, nanoparticles offer a promising therapeutic platform for the development of new and effective biofilm-targeting approaches. 


\subsection{Surfactants, Amino-Acids, Metal Chelators, and Various Enzymes}

Surfactants show antibiofilm activity by interacting with various cellular components, such as proteins and lipids, reducing microbial cell growth and viability [250-252]. Sodium dodecyl sulfate (SDS) promotes biofilm dispersion by causing cavity formation within biofilms [251]. Several other surfactants, such as surfactin, rhamnolipids, Tween 20, cetyltrimethylammonium bromide (CTAB), and Triton X-100, have also been reported to cause biofilm disruption [253,254]. The disintegration of biofilms can also be achieved by amino acids (D-cysteine (Cys), D- or L-aspartic acid (Asp) and D-or L-glutamic acid (Glu), which have been reported for various bacterial species including streptococci $[243,255]$.

\subsection{Phages Therapy}

Bacteriophages may also be used for their antibiofilm properties. They have the advantage of being specific for bacterial strains and of having a rapid, targeted action, reducing the development of resistance [256]. Even for resistant bacteria, phages are often bacteriocidal. The successful application of bacteriophages or bacteriophage-encoded lysins was shown for S. pyogenes and S. suis [257-259]. More recently, a novel S. mutans phage was isolated showing antibiofilm activity [260] and the use of a bacteriophage-encoded lysin against $S$. mutans biofilms could be demonstrated [261].

\section{Conclusions and Future Prospective}

Biofilms are often essential in the development of streptococcal infections and represent an important clinical challenge affecting morbidity and mortality. They provide defense against antibiotics and protection from the immune system, therefore treatment with antimicrobial drugs alone is difficult. Addressing this situation requires a better understanding of the underlying molecular mechanisms. In this review, we discuss the role of virulence factors, pili, and surface proteins and regulators associated with streptococcal biofilms. Targeting different aspects of biofilm production, promising antibiofilm approaches can be envisioned. Various in vitro studies show that streptococcal biofilms can be attacked by addressing quorum sensing systems, bacteriocins, EPSs, AMPs, nanodrugs, enzymes, surfactants, and phages. Thus, biofilms that represent a crucial part in the development Streptococcal infections can be a key target for novel therapeutic strategies.

Author Contributions: P.Y., S.V., V.Y. and B.S. contributed to the conception of the review article. P.Y., S.V., R.B., V.Y. and B.S. drafted the work. P.Y., S.V., R.B., M.K., M.D., A.K.J., V.Y. and B.S. wrote the review article. P.Y. and B.S. revised it critically. P.Y., S.V., R.B., M.K. and B.S. helped in literature search. P.Y. and B.S. gave Final approval of the version to be published. All authors have read and agreed to the published version of the manuscript.

Funding: This work was supported, in part, by a grant to PY, ECR/2015/000431 from Science and Engineering Research Board, Department of Science and Technology, Government of India. The work of B.S. and R.B. was supported by the Deutsche Forschungsgemeinschaft under project CRC1279. V.Y. acknowledges Ramalingaswamy fellowship, BT/RLF/RE-ENTRY/29/2014 from the Department of Biotechnology, Government of India.

Conflicts of Interest: The authors declare no conflict of interest.

\section{References}

1. Donlan, R.M. Biofilms: Microbial Life on Surfaces. Emerg. Infect. Dis. 2002, 8, 881-890. [CrossRef] [PubMed]

2. Hall-Stoodley, L.; Costerton, J.W.; Stoodley, P. Bacterial biofilms: From the Natural environment to infectious diseases. Nat. Rev. Microbiol. 2004, 2, 95-108. [CrossRef] [PubMed]

3. Marrie, T.J.; Nelligan, J.; Costerton, J.W. A scanning and transmission electron microscopic study of an infected endocardial pacemaker lead. Circulation 1982, 66, 1339-1341. [CrossRef] [PubMed]

4. Hall, C.W.; Mah, T.-F. Molecular mechanisms of biofilm-based antibiotic resistance and tolerance in pathogenic bacteria. FEMS Microbiol. Rev. 2017, 41, 276-301. [CrossRef] [PubMed]

5. Garrett, T.; Bhakoo, M.; Zhang, Z. Bacterial adhesion and biofilms on surfaces. Prog. Nat. Sci. $2008,18$. [CrossRef]

6. Conley, J.; Olson, M.E.; Cook, L.S.; Ceri, H.; Phan, V.; Davies, H.D. Biofilm Formation by Group A Streptococci: Is There a Relationship with Treatment Failure? J. Clin. Microbiol. 2003, 41, 4043-4048. [CrossRef] 
7. Cox, G.; Wright, G.D. Intrinsic antibiotic resistance: Mechanisms, origins, challenges and solutions. Int. J. Med. Microbiol. 2013, 303, 287-292. [CrossRef]

8. Blair, J.M.A.; Webber, M.A.; Baylay, A.J.; Ogbolu, D.O.; Piddock, L.J.V. Molecular mechanisms of antibiotic resistance. Nat. Rev. Microbiol. 2015, 13, 42-51. [CrossRef]

9. Baldassarri, L.; Creti, R.; Recchia, S.; Imperi, M.; Facinelli, B.; Giovanetti, E.; Pataracchia, M.; Alfarone, G.; Orefici, G. Therapeutic Failures of Antibiotics Used To Treat Macrolide-Susceptible Streptococcus pyogenes Infections May Be Due to Biofilm Formation. J. Clin. Microbiol. 2006, 44, 2721-2727. [CrossRef]

10. Ogawa, T.; Terao, Y.; Okuni, H.; Ninomiya, K.; Sakata, H.; Ikebe, K.; Maeda, Y.; Kawabata, S. Biofilm formation or internalization into epithelial cells enable Streptococcus pyogenes to evade antibiotic eradication in patients with pharyngitis. Microb. Pathog. 2011, 51, 58-68. [CrossRef]

11. Davey, M.E.; O'Toole, G.A. Microbial biofilms: From ecology to molecular genetics. Microbiol. Mol. Biol. Rev. 2000, 64, 847-867. [CrossRef]

12. Berlanga, M.; Guerrero, R. Living together in biofilms: The microbial cell factory and its biotechnological implications. Microb. Cell Factories 2016, 15, 165. [CrossRef]

13. Flemming, H.-C.; Wingender, J. The biofilm matrix. Nat. Rev. Microbiol. 2010, 8, 623-633. [CrossRef] [PubMed]

14. Kaplan, J.B. Biofilm dispersal: Mechanisms, clinical implications, and potential therapeutic uses. J. Dent. Res. 2010, 89, 205-218. [CrossRef] [PubMed]

15. Stewart, P.S.; Franklin, M.J. Physiological heterogeneity in biofilms. Nat. Rev. Microbiol. 2008, 6, $199-210$. [CrossRef] [PubMed]

16. Boles, B.R.; Singh, P.K. Endogenous oxidative stress produces diversity and adaptability in biofilm communities. Proc. Natl. Acad. Sci. USA 2008, 105, 12503-12508. [CrossRef]

17. Costerton, J.W.; Cheng, K.J.; Geesey, G.G.; Ladd, T.I.; Nickel, J.C.; Dasgupta, M.; Marrie, T.J. Bacterial biofilms in nature and disease. Annu. Rev. Microbiol. 1987, 41, 435-464. [CrossRef]

18. Stewart, P.S.; William Costerton, J. Antibiotic resistance of bacteria in biofilms. Lancet 2001, 358, $135-138$. [CrossRef]

19. Ates, O. Systems Biology of Microbial Exopolysaccharides Production. Front. Bioeng. Biotechnol. $2015,3$. [CrossRef]

20. Nwodo, U.U.; Green, E.; Okoh, A.I. Bacterial exopolysaccharides: Functionality and prospects. Int. J. Mol. Sci. 2012, 13, 14002-14015. [CrossRef]

21. Koo, H.; Xiao, J.; Klein, M.; Jeon, J. Exopolysaccharides Produced by Streptococcus mutans Glucosyltransferases Modulate the Establishment of Microcolonies within Multispecies Biofilms. J. Bacteriol. 2010, 192, 3024-3032. [CrossRef] [PubMed]

22. Moscoso, M.; Claverys, J.-P. Release of DNA into the medium by competent Streptococcus pneumoniae: Kinetics, mechanism and stability of the liberated DNA. Mol. Microbiol. 2004, 54, 783-794. [CrossRef] [PubMed]

23. Oggioni, M.R.; Trappetti, C.; Kadioglu, A.; Cassone, M.; Iannelli, F.; Ricci, S.; Andrew, P.W.; Pozzi, G. Switch from planktonic to sessile life: A major event in pneumococcal pathogenesis. Mol. Microbiol. 2006, 61, 1196-1210. [CrossRef] [PubMed]

24. Allegrucci, M.; Sauer, K. Characterization of colony morphology variants isolated from Streptococcus pneumoniae biofilms. J. Bacteriol. 2007, 189, 2030-2038. [CrossRef]

25. Camilli, R.; Pantosti, A.; Baldassarri, L. Contribution of serotype and genetic background to biofilm formation by Streptococcus pneumoniae. Eur. J. Clin. Microbiol. Infect. Dis. Off. Publ. Eur. Soc. Clin. Microbiol. 2011, 30, 97-102. [CrossRef]

26. Okshevsky, M.; Regina, V.R.; Meyer, R.L. Extracellular DNA as a target for biofilm control. Curr. Opin. Biotechnol. 2015, 33, 73-80. [CrossRef]

27. Moscoso, M.; García, E.; López, R. Biofilm Formation by Streptococcus pneumoniae: Role of Choline, Extracellular DNA, and Capsular Polysaccharide in Microbial Accretion. J. Bacteriol. 2006, 188, 7785-7795. [CrossRef]

28. Carrolo, M.; Frias, M.J.; Pinto, F.R.; Melo-Cristino, J.; Ramirez, M. Prophage spontaneous activation promotes DNA release enhancing biofilm formation in Streptococcus pneumoniae. PLoS ONE 2010, 5, e15678. [CrossRef]

29. Hall-Stoodley, L.; Nistico, L.; Sambanthamoorthy, K.; Dice, B.; Nguyen, D.; Mershon, W.J.; Johnson, C.; $\mathrm{Ze} \mathrm{Hu}$, F.; Stoodley, P.; Ehrlich, G.D.; et al. Characterization of biofilm matrix, degradation by DNase treatment and evidence of capsule downregulation in Streptococcus pneumoniae clinical isolates. BMC Microbiol. 2008, 8, 173. [CrossRef] 
30. Fong, J.N.C.; Yildiz, F.H. Biofilm Matrix Proteins. Microbiol. Spectr. 2015, 3. [CrossRef]

31. Lasa, I.; Penadés, J.R. Bap: A family of surface proteins involved in biofilm formation. Res. Microbiol. 2006, 157, 99-107. [CrossRef] [PubMed]

32. Toledo-Arana, A.; Valle, J.; Solano, C.; Arrizubieta, M.J.; Cucarella, C.; Lamata, M.; Amorena, B.; Leiva, J.; Penadés, J.R.; Lasa, I. The enterococcal surface protein, Esp, is involved in Enterococcus faecalis biofilm formation. Appl. Environ. Microbiol. 2001, 67, 4538-4545. [CrossRef] [PubMed]

33. Oli, M.W.; Otoo, H.N.; Crowley, P.J.; Heim, K.P.; Nascimento, M.M.; Ramsook, C.B.; Lipke, P.N.; Brady, L.J. Functional amyloid formation by Streptococcus mutans. Microbiology 2012, 158, 2903-2916. [CrossRef] [PubMed]

34. Garcia, M.C.; Lee, J.T.; Ramsook, C.B.; Alsteens, D.; Dufrêne, Y.F.; Lipke, P.N. A Role for Amyloid in Cell Aggregation and Biofilm Formation. PLoS ONE 2011, 6. [CrossRef] [PubMed]

35. Banas, J.A.; Vickerman, M.M. Glucan-binding Proteins of the Oral Streptococci. Crit. Rev. Oral Biol. Med. 2003, 14, 89-99. [CrossRef] [PubMed]

36. Matsumoto-Nakano, M. Role of Streptococcus mutans surface proteins for biofilm formation. Jpn. Dent. Sci. Rev. 2018, 54, 22-29. [CrossRef]

37. Kaplan, J.B.; Ragunath, C.; Ramasubbu, N.; Fine, D.H. Detachment of Actinobacillus actinomycetemcomitans Biofilm Cells by an Endogenous $\beta$-Hexosaminidase Activity. J. Bacteriol. 2003, 185, 4693-4698. [CrossRef]

38. Young, C.; Holder, R.C.; Dubois, L.; Reid, S.D. Streptococcus pyogenes biofilm. In Streptococcus pyogenes: Basic Biology to Clinical Manifestations; Ferretti, J.J., Stevens, D.L., Fischetti, V.A., Eds.; University of Oklahoma Health Sciences Center: Oklahoma City, OK, USA, 2016.

39. Fiedler, T.; Köller, T.; Kreikemeyer, B. Streptococcus pyogenes biofilms-formation, biology, and clinical relevance. Front. Cell. Infect. Microbiol. 2015, 5. [CrossRef]

40. Shafreen, R.M.B.; Srinivasan, S.; Manisankar, P.; Pandian, S.K. Biofilm formation by Streptococcus pyogenes: Modulation of exopolysaccharide by fluoroquinolone derivatives. J. Biosci. Bioeng. 2011, 112, 345-350. [CrossRef]

41. Lembke, C.; Podbielski, A.; Hidalgo-Grass, C.; Jonas, L.; Hanski, E.; Kreikemeyer, B. Characterization of Biofilm Formation by Clinically Relevant Serotypes of Group A Streptococci. Appl. Environ. Microbiol. 2006, 72, 12. [CrossRef]

42. Thenmozhi, R.; Balaji, K.; Kumar, R.; Rao, T.S.; Pandian, S.K. Characterization of biofilms in different clinical M serotypes of Streptococcus pyogenes. J. Basic Microbiol. 2011, 51, 196-204. [CrossRef] [PubMed]

43. Rosini, R.; Margarit, I. Biofilm formation by Streptococcus agalactiae: Influence of environmental conditions and implicated virulence factors. Front. Cell. Infect. Microbiol. 2015, 5. [CrossRef]

44. Kaur, H.; Kumar, P.; Ray, P.; Kaur, J.; Chakraborti, A. Biofilm formation in clinical isolates of group B streptococci from north India. Microb. Pathog. 2009, 46, 321-327. [CrossRef] [PubMed]

45. Konto-Ghiorghi, Y.; Mairey, E.; Mallet, A.; Duménil, G.; Caliot, E.; Trieu-Cuot, P.; Dramsi, S. Dual role for pilus in adherence to epithelial cells and biofilm formation in Streptococcus agalactiae. PLoS Pathog. 2009, 5, e1000422. [CrossRef]

46. Rinaudo, C.D.; Rosini, R.; Galeotti, C.L.; Berti, F.; Necchi, F.; Reguzzi, V.; Ghezzo, C.; Telford, J.L.; Grandi, G.; Maione, D. Specific Involvement of Pilus Type 2a in Biofilm Formation in Group B Streptococcus. PLoS ONE 2010, 5, e9216. [CrossRef] [PubMed]

47. Donlan, R.M.; Costerton, J.W. Biofilms: Survival Mechanisms of Clinically Relevant Microorganisms. Clin. Microbiol. Rev. 2002, 15, 167-193. [CrossRef] [PubMed]

48. D’Urzo, N.; Martinelli, M.; Pezzicoli, A.; De Cesare, V.; Pinto, V.; Margarit, I.; Telford, J.L.; Maione, D. Acidic pH Strongly Enhances In Vitro Biofilm Formation by a Subset of Hypervirulent ST-17 Streptococcus agalactiae Strains. Appl. Environ. Microbiol. 2014, 80, 2176-2185. [CrossRef] [PubMed]

49. Brandt, C.M.; Spellerberg, B. Human infections due to Streptococcus dysgalactiae subspecies equisimilis. Clin. Infect. Dis. 2009, 49, 766-772. [CrossRef]

50. Ma, J.-S.; Chen, S.-Y.; Lo, H.-H. Biofilm formation of beta-hemolytic group G Streptococcus dysgalactiae subspecies equisimilis isolates and its association with emm polymorphism. APMIS Acta Pathol. Microbiol. Immunol. Scand. 2017, 125, 1027-1032. [CrossRef]

51. Genteluci, G.L.; Silva, L.G.; Souza, M.C.; Glatthardt, T.; de Mattos, M.C.; Ejzemberg, R.; Alviano, C.S.; Figueiredo, A.M.S.; Ferreira-Carvalho, B.T. Assessment and characterization of biofilm formation among 
human isolates of Streptococcus dysgalactiae subsp. equisimilis. Int. J. Med. Microbiol. 2015, 305, 937-947. [CrossRef]

52. Chao, Y.; Marks, L.R.; Pettigrew, M.M.; Hakansson, A.P. Streptococcus pneumoniae biofilm formation and dispersion during colonization and disease. Front. Cell. Infect. Microbiol. 2015, 4. [CrossRef] [PubMed]

53. Domenech, M.; García, E.; Moscoso, M. Biofilm formation in Streptococcus pneumoniae. Microb. Biotechnol. 2012, 5, 455-465. [CrossRef] [PubMed]

54. Sanchez, C.J.; Kumar, N.; Lizcano, A.; Shivshankar, P.; Dunning Hotopp, J.C.; Jorgensen, J.H.; Tettelin, H.; Orihuela, C.J. Streptococcus pneumoniae in Biofilms Are Unable to Cause Invasive Disease Due to Altered Virulence Determinant Production. PLoS ONE 2011, 6. [CrossRef] [PubMed]

55. Domenech, M.; García, E.; Prieto, A.; Moscoso, M. Insight into the composition of the intercellular matrix of Streptococcus pneumoniae biofilms. Environ. Microbiol. 2012, 15. [CrossRef]

56. Marks, L.R.; Davidson, B.A.; Knight, P.R.; Hakansson, A.P. Interkingdom signaling induces Streptococcus pneumoniae biofilm dispersion and transition from asymptomatic colonization to disease. mBio 2013, 4 . [CrossRef]

57. Rickard, A.H.; Gilbert, P.; High, N.J.; Kolenbrander, P.E.; Handley, P.S. Bacterial coaggregation: An integral process in the development of multi-species biofilms. Trends Microbiol. 2003, 11, 94-100. [CrossRef]

58. Diaz, P.I.; Chalmers, N.I.; Rickard, A.H.; Kong, C.; Milburn, C.L.; Palmer, R., Jr.; Kolenbrander, P.E. Molecular characterization of subject-specific oral microflora during initial colonization of enamel. Appl. Environ. Microbiol. 2006, 72, 2837-2848. [CrossRef]

59. Ammann, T.W.; Belibasakis, G.N.; Thurnheer, T. Impact of Early Colonizers on In Vitro Subgingival Biofilm Formation. PLoS ONE 2013, 8. [CrossRef]

60. Souza, J.G.S.; Bertolini, M.; Thompson, A.; Mansfield, J.M.; Grassmann, A.A.; Maas, K.; Caimano, M.J.; Barao, V.A.R.; Vickerman, M.M.; Dongari-Bagtzoglou, A. Role of glucosyltransferase R in biofilm interactions between Streptococcus oralis and Candida albicans. ISME J. 2020, 14, 1207-1222. [CrossRef]

61. McNab, R.; Ford, S.K.; El-Sabaeny, A.; Barbieri, B.; Cook, G.S.; Lamont, R.J. LuxS-Based Signaling in Streptococcus gordonii: Autoinducer 2 Controls Carbohydrate Metabolism and Biofilm Formation with Porphyromonas gingivalis. J. Bacteriol. 2003, 185, 274-284. [CrossRef]

62. Zhu, B.; Ge, X.; Stone, V.; Kong, X.; El-Rami, F.; Liu, Y.; Kitten, T.; Xu, P. ciaR impacts biofilm formation by regulating an arginine biosynthesis pathway in Streptococcus sanguinis SK36. Sci. Rep. 2017, 7, 17183. [CrossRef] [PubMed]

63. Vickerman, M.M.; Clewell, D.B.; Jones, G.W. Sucrose-promoted accumulation of growing glucosyltransferase variants of Streptococcus gordonii on hydroxyapatite surfaces. Infect. Immun. 1991, 59, 3523-3530. [CrossRef] [PubMed]

64. Cavalcanti, I.M.G.; Del Bel Cury, A.A.; Jenkinson, H.F.; Nobbs, A.H. Interactions between Streptococcus oralis, Actinomyces oris, and Candida albicans in the development of multispecies oral microbial biofilms on salivary pellicle. Mol. Oral Microbiol. 2017, 32, 60-73. [CrossRef]

65. Fahim, A.; Himratul-Aznita, W.H.; Abdul-Rahman, P.S. Polymicrobial interactions between Streptococcus mitis, Streptococcus sanguinis and oral associated Candida albicans on an in vitro salivary biofilm and differential expression of ALS1, ALS2 and ALS3 genes. Biotechnol. Biotechnol. Equip. 2019, 33, 338-346. [CrossRef]

66. Presterl, E.; Grisold, A.J.; Reichmann, S.; Hirschl, A.M.; Georgopoulos, A.; Graninger, W. Viridans streptococci in endocarditis and neutropenic sepsis: Biofilm formation and effects of antibiotics. J. Antimicrob. Chemother. 2005, 55, 45-50. [CrossRef] [PubMed]

67. Petersen, F.C.; Pecharki, D.; Scheie, A.A. Biofilm Mode of Growth of Streptococcus intermedius Favored by a Competence-Stimulating Signaling Peptide. J. Bacteriol. 2004, 186, 6327-6331. [CrossRef]

68. Petersen, F.C.; Ahmed, N.A.A.M.; Naemi, A.; Scheie, A.A. LuxS-mediated signalling in Streptococcus anginosus and its role in biofilm formation. Antonie Van Leeuwenhoek 2006, 90, 109-121. [CrossRef]

69. Perez-Tanoira, R.; Aarnisalo, A.; Haapaniemi, A.; Saarinen, R.; Kuusela, P.; Kinnari, T.J. Bacterial biofilm in salivary stones. Eur. Arch. Otorhinolaryngol 2019, 276, 1815-1822. [CrossRef]

70. Tavernier, S.; Sass, A.; De Bruyne, M.; Baeke, F.; De Rycke, R.; Crabbé, A.; Vandecandelaere, I.; Van Nieuwerburgh, F.; Coenye, T. Decreased susceptibility of Streptococcus anginosus to vancomycin in a multispecies biofilm is due to increased thickness of the cell wall. J. Antimicrob. Chemother. 2018, 73, 2323-2330. [CrossRef]

71. Guo, L.; McLean, J.S.; Lux, R.; He, X.; Shi, W. The well-coordinated linkage between acidogenicity and aciduricity via insoluble glucans on the surface of Streptococcus mutans. Sci. Rep. 2016, 5, 18015. [CrossRef] 
72. Nobbs, A.H.; Lamont, R.J.; Jenkinson, H.F. Streptococcus Adherence and Colonization. Microbiol. Mol. Biol. Rev. 2009, 73, 407-450. [CrossRef] [PubMed]

73. Demuth, D.R.; Lammey, M.S.; Huck, M.; Lally, E.T.; Malamud, D. Comparison of Streptococcus mutans and Streptococcus sanguis receptors for human salivary agglutinin. Microb. Pathog. 1990, 9, 199-211. [CrossRef]

74. Telford, J.L.; Barocchi, M.A.; Margarit, I.; Rappuoli, R.; Grandi, G. Pili in gram-positive pathogens. Nat. Rev. Microbiol. 2006, 4, 509-519. [CrossRef] [PubMed]

75. Mora, M.; Bensi, G.; Capo, S.; Falugi, F.; Zingaretti, C.; Manetti, A.G.O.; Maggi, T.; Taddei, A.R.; Grandi, G.; Telford, J.L. Group A Streptococcus produce pilus-like structures containing protective antigens and Lancefield T antigens. Proc. Natl. Acad. Sci. USA 2005, 102, 15641-15646. [CrossRef]

76. Lauer, P.; Rinaudo, C.D.; Soriani, M.; Margarit, I.; Maione, D.; Rosini, R.; Taddei, A.R.; Mora, M.; Rappuoli, R.; Grandi, G.; et al. Genome analysis reveals pili in Group B Streptococcus. Science 2005, 309, 105. [CrossRef]

77. Rosini, R.; Rinaudo, C.D.; Soriani, M.; Lauer, P.; Mora, M.; Maione, D.; Taddei, A.; Santi, I.; Ghezzo, C.; Brettoni, C.; et al. Identification of novel genomic islands coding for antigenic pilus-like structures in Streptococcus agalactiae. Mol. Microbiol. 2006, 61, 126-141. [CrossRef]

78. Barocchi, M.A.; Ries, J.; Zogaj, X.; Hemsley, C.; Albiger, B.; Kanth, A.; Dahlberg, S.; Fernebro, J.; Moschioni, M.; Masignani, V.; et al. A pneumococcal pilus influences virulence and host inflammatory responses. Proc. Natl. Acad. Sci. USA 2006, 103, 2857-2862. [CrossRef]

79. Dramsi, S.; Trieu-Cuot, P.; Bierne, H. Sorting sortases: A nomenclature proposal for the various sortases of Gram-positive bacteria. Res. Microbiol. 2005, 156, 289-297. [CrossRef]

80. Hilleringmann, M.; Ringler, P.; Müller, S.A.; De Angelis, G.; Rappuoli, R.; Ferlenghi, I.; Engel, A. Molecular architecture of Streptococcus pneumoniae TIGR4 pili. EMBO J. 2009, 28, 3921-3930. [CrossRef]

81. Becherelli, M.; Manetti, A.G.O.; Buccato, S.; Viciani, E.; Ciucchi, L.; Mollica, G.; Grandi, G.; Margarit, I. The ancillary protein 1 of Streptococcus pyogenes FCT-1 pili mediates cell adhesion and biofilm formation through heterophilic as well as homophilic interactions. Mol. Microbiol. 2012, 83, 1035-1047. [CrossRef]

82. Manetti, A.G.O.; Zingaretti, C.; Falugi, F.; Capo, S.; Bombaci, M.; Bagnoli, F.; Gambellini, G.; Bensi, G.; Mora, M.; Edwards, A.M.; et al. Streptococcus pyogenes pili promote pharyngeal cell adhesion and biofilm formation. Mol. Microbiol. 2007, 64, 968-983. [CrossRef]

83. Manetti, A.G.O.; Köller, T.; Becherelli, M.; Buccato, S.; Kreikemeyer, B.; Podbielski, A.; Grandi, G.; Margarit, I. Environmental Acidification Drives S. pyogenes Pilus Expression and Microcolony Formation on Epithelial Cells in a FCT-Dependent Manner. PLoS ONE 2010, 5, e13864. [CrossRef] [PubMed]

84. Kimura, K.R.; Nakata, M.; Sumitomo, T.; Kreikemeyer, B.; Podbielski, A.; Terao, Y.; Kawabata, S. Involvement of T6 Pili in Biofilm Formation by Serotype M6 Streptococcus pyogenes. J. Bacteriol. 2012, 194, 804-812. [CrossRef]

85. Nakata, M.; Kimura, K.R.; Sumitomo, T.; Wada, S.; Sugauchi, A.; Oiki, E.; Higashino, M.; Kreikemeyer, B.; Podbielski, A.; Okahashi, N.; et al. Assembly Mechanism of FCT Region Type 1 Pili in Serotype M6 Streptococcus pyogenes. J. Biol. Chem. 2011, 286, 37566-37577. [CrossRef]

86. Koller, T.; Manetti, A.G.O.; Kreikemeyer, B.; Lembke, C.; Margarit, I.; Grandi, G.; Podbielski, A. Typing of the pilus-protein-encoding FCT region and biofilm formation as novel parameters in epidemiological investigations of Streptococcus pyogenes isolates from various infection sites. J. Med. Microbiol. 2010, 59, 442-452. [CrossRef] [PubMed]

87. Edwards, A.M.; Manetti, A.G.O.; Falugi, F.; Zingaretti, C.; Capo, S.; Buccato, S.; Bensi, G.; Telford, J.L.; Margarit, I.; Grandi, G. Scavenger receptor gp340 aggregates group A streptococci by binding pili. Mol. Microbiol. 2008, 68, 1378-1394. [CrossRef] [PubMed]

88. Falugi, F.; Zingaretti, C.; Pinto, V.; Mariani, M.; Amodeo, L.; Manetti, A.G.O.; Capo, S.; Musser, J.M.; Orefici, G.; Margarit, I.; et al. Sequence variation in group A Streptococcus pili and association of pilus backbone types with lancefield T serotypes. J. Infect. Dis. 2008, 198, 1834-1841. [CrossRef] [PubMed]

89. Kratovac, Z.; Manoharan, A.; Luo, F.; Lizano, S.; Bessen, D.E. Population genetics and linkage analysis of loci within the FCT region of Streptococcus pyogenes. J. Bacteriol. 2007, 189, 1299-1310. [CrossRef]

90. Kreikemeyer, B.; Gámez, G.; Margarit, I.; Giard, J.-C.; Hammerschmidt, S.; Hartke, A.; Podbielski, A. Genomic organization, structure, regulation and pathogenic role of pilus constituents in major pathogenic Streptococci and Enterococci. Int. J. Med. Microbiol. 2011, 301, 240-251. [CrossRef]

91. Bessen, D.E.; Kalia, A. Genomic localization of a T serotype locus to a recombinatorial zone encoding extracellular matrix-binding proteins in Streptococcus pyogenes. Infect. Immun. 2002, 70, 1159-1167. [CrossRef] 
92. Kreikemeyer, B.; Nakata, M.; Oehmcke, S.; Gschwendtner, C.; Normann, J.; Podbielski, A. Streptococcus pyogenes collagen type I-binding Cpa surface protein. Expression profile, binding characteristics, biological functions, and potential clinical impact. J. Biol. Chem. 2005, 280, 33228-33239. [CrossRef] [PubMed]

93. Maisey, H.C.; Hensler, M.; Nizet, V.; Doran, K.S. Group B Streptococcal Pilus Proteins Contribute to Adherence to and Invasion of Brain Microvascular Endothelial Cells. J. Bacteriol. 2007, 189, 1464-1467. [CrossRef]

94. Lazzarin, M.; Mu, R.; Fabbrini, M.; Ghezzo, C.; Rinaudo, C.D.; Doran, K.S.; Margarit, I. Contribution of pilus type $2 \mathrm{~b}$ to invasive disease caused by a Streptococcus agalactiae ST-17 strain. BMC Microbiol. 2017, 17, 148. [CrossRef] [PubMed]

95. Maisey, H.C.; Quach, D.; Hensler, M.E.; Liu, G.Y.; Gallo, R.L.; Nizet, V.; Doran, K.S. A group B streptococcal pilus protein promotes phagocyte resistance and systemic virulence. FASEB J. 2008, 22, 1715-1724. [CrossRef]

96. Armistead, B.; Oler, E.; Adams Waldorf, K.; Rajagopal, L. The Double Life of Group B Streptococcus: Asymptomatic Colonizer and Potent Pathogen. J. Mol. Biol. 2019, 431, 2914-2931. [CrossRef]

97. Martins, E.R.; Andreu, A.; Melo-Cristino, J.; Ramirez, M. Distribution of Pilus Islands in Streptococcus agalactiae That Cause Human Infections: Insights into Evolution and Implication for Vaccine Development. Clin. Vaccine Immunol. 2013, 20, 313-316. [CrossRef] [PubMed]

98. Parker, R.E.; Laut, C.; Gaddy, J.A.; Zadoks, R.N.; Davies, H.D.; Manning, S.D. Association between genotypic diversity and biofilm production in group B Streptococcus. BMC Microbiol. 2016, 16, 86. [CrossRef]

99. Pang, M.; Sun, L.; He, T.; Bao, H.; Zhang, L.; Zhou, Y.; Zhang, H.; Wei, R.; Liu, Y.; Wang, R. Molecular and virulence characterization of highly prevalent Streptococcus agalactiae circulated in bovine dairy herds. Vet. Res. 2017, 48, 65. [CrossRef]

100. Alvim, D.C.S.S.; Ferreira, A.F.M.; Leal, M.A.; Oliveira, L.M.A.; Botelho, A.M.N.; Botelho, A.C.N.; Figueiredo, A.M.S.; Fracalanzza, S.E.L.; Teixeira, L.M.; Pinto, T.C.A. Biofilm production and distribution of pilus variants among Streptococcus agalactiae isolated from human and animal sources. Biofouling 2019, 35, 938-944. [CrossRef]

101. Soriani, M.; Telford, J.L. Relevance of pili in pathogenic streptococci pathogenesis and vaccine development. Future Microbiol. 2010, 5, 735-747. [CrossRef]

102. Springman, A.; Lacher, D.W.; Waymire, E.A.; Wengert, S.L.; Singh, P.; Zadoks, R.N.; Davies, H.; Manning, S.D. Pilus distribution among lineages of group b streptococcus: An evolutionary and clinical perspective. BMC Microbiol. 2014, 14, 159. [CrossRef] [PubMed]

103. Becke, T.D.; Ness, S.; Kaufmann, B.K.; Hartmann, B.; Schilling, A.F.; Sudhop, S.; Hilleringmann, M.; Clausen-Schaumann, H. Pilus-1 Backbone Protein RrgB of Streptococcus pneumoniae Binds Collagen I in a Force-Dependent Way. ACS Nano 2019, 13, 7155-7165. [CrossRef] [PubMed]

104. Paterson, N.; Baker, E. Structure of the Full-Length Major Pilin from Streptococcus pneumoniae: Implications for Isopeptide Bond Formation in Gram-Positive Bacterial Pili. PLoS ONE 2011, 6, e22095. [CrossRef] [PubMed]

105. Shaik, M.M.; Maccagni, A.; Tourcier, G.; Di Guilmi, A.M.; Dessen, A. Structural Basis of Pilus Anchoring by the Ancillary Pilin RrgC of Streptococcus pneumoniae. J. Biol. Chem. 2014, 289, 16988-16997. [CrossRef]

106. Muñoz-Elías, E.J.; Marcano, J.; Camilli, A. Isolation of Streptococcus pneumoniae Biofilm Mutants and Their Characterization during Nasopharyngeal Colonization. Infect. Immun. 2008, 76, 5049-5061. [CrossRef]

107. Okahashi, N.; Okinaga, T.; Sakurai, A.; Terao, Y.; Nakata, M.; Nakashima, K.; Shintani, S.; Kawabata, S.; Ooshima, T.; Nishihara, T. Streptococcus sanguinis induces foam cell formation and cell death of macrophages in association with production of reactive oxygen species. FEMS Microbiol. Lett. 2011, 323, 164-170. [CrossRef]

108. Zähner, D.; Gandhi, A.R.; Yi, H.; Stephens, D.S. Mitis Group Streptococci Express Variable Pilus Islet 2 Pili. PLOS ONE 2011, 6, e25124. [CrossRef]

109. Foster, T.J. The MSCRAMM Family of Cell-Wall-Anchored Surface Proteins of Gram-Positive Cocci. Trends Microbiol. 2019, 27, 927-941. [CrossRef]

110. Brady, L.J.; Maddocks, S.E.; Larson, M.R.; Forsgren, N.; Persson, K.; Deivanayagam, C.C.; Jenkinson, H.F. The changing faces of Streptococcus antigen I/II polypeptide family adhesins. Mol. Microbiol. 2010, 77, 276-286. [CrossRef]

111. Lukomski, S.; Bachert, B.A.; Squeglia, F.; Berisio, R. Collagen-like proteins of pathogenic streptococci. Mol. Microbiol. 2017, 103, 919-930. [CrossRef]

112. Maestro, B.; Sanz, J.M. Choline Binding Proteins from Streptococcus pneumoniae: A Dual Role as Enzybiotics and Targets for the Design of New Antimicrobials. Antibiotics 2016, 5, 21. [CrossRef] [PubMed] 
113. Caswell, C.C.; Oliver-Kozup, H.; Han, R.; Lukomska, E.; Lukomski, S. Scl1, the multifunctional adhesin of group A Streptococcus, selectively binds cellular fibronectin and laminin, and mediates pathogen internalization by human cells. FEMS Microbiol. Lett. 2010, 303, 61-68. [CrossRef] [PubMed]

114. Oliver-Kozup, H.; Martin, K.H.; Schwegler-Berry, D.; Green, B.J.; Betts, C.; Shinde, A.V.; Van De Water, L.; Lukomski, S. The group A streptococcal collagen-like protein-1, Scl1, mediates biofilm formation by targeting the extra domain A-containing variant of cellular fibronectin expressed in wounded tissue. Mol. Microbiol. 2013, 87, 672-689. [CrossRef] [PubMed]

115. Wozniak, A.; Scioscia, N.; Geoffroy, E.; Ponce, I.; García, P. Importance of adhesins in the recurrence of pharyngeal infections caused by Streptococcus pyogenes. J. Med. Microbiol. 2017, 66, 517-525. [CrossRef] [PubMed]

116. Lukomski, S.; Nakashima, K.; Abdi, I.; Cipriano, V.J.; Ireland, R.M.; Reid, S.D.; Adams, G.G.; Musser, J.M. Identification and characterization of the scl gene encoding a group A Streptococcus extracellular protein virulence factor with similarity to human collagen. Infect. Immun. 2000, 68, 6542-6553. [CrossRef] [PubMed]

117. Rasmussen, M.; Edén, A.; Björck, L. SclA, a novel collagen-like surface protein of Streptococcus pyogenes. Infect. Immun. 2000, 68, 6370-6377. [CrossRef] [PubMed]

118. Oliver-Kozup, H.A.; Elliott, M.; Bachert, B.A.; Martin, K.H.; Reid, S.D.; Schwegler-Berry, D.E.; Green, B.J.; Lukomski, S. The streptococcal collagen-like protein-1 (Scl1) is a significant determinant for biofilm formation by group A Streptococcus. BMC Microbiol. 2011, 11, 262. [CrossRef]

119. Courtney, H.S.; Ofek, I.; Penfound, T.; Nizet, V.; Pence, M.A.; Podbielbski, A.; Hasty, D.L.; Dale, J.B. Relationship between Expression of the Family of M Proteins and Lipoteichoic Acid to Hydrophobicity and Biofilm Formation in Streptococcus pyogenes. PLoS ONE 2009, 4, 10. [CrossRef]

120. Hall, M.; Nylander, S.; Jenkinson, H.F.; Persson, K. Structure of the C-terminal domain of AspA (antigen I/II-family) protein from Streptococcus pyogenes. FEBS Open Bio 2014, 4, 283-289. [CrossRef]

121. Maddocks, S.E.; Wright, C.J.; Nobbs, A.H.; Brittan, J.L.; Franklin, L.; Strömberg, N.; Kadioglu, A.; Jepson, M.A.; Jenkinson, H.F. Streptococcus pyogenes antigen I/II-family polypeptide AspA shows differential ligand-binding properties and mediates biofilm formation. Mol. Microbiol. 2011, 81, 1034-1049. [CrossRef]

122. Connolly, K.; Braden, A.; Holder, R.; Reid, S. Srv Mediated Dispersal of Streptococcal Biofilms Through SpeB Is Observed in CovRS+ Strains. PLoS ONE 2011, 6, e28640. [CrossRef] [PubMed]

123. Buscetta, M.; Papasergi, S.; Firon, A.; Pietrocola, G.; Biondo, C.; Mancuso, G.; Midiri, A.; Romeo, L.; Teti, G.; Speziale, P.; et al. FbsC, a Novel Fibrinogen-binding Protein, Promotes Streptococcus agalactiae-Host Cell Interactions. J. Biol. Chem. 2014, 289, 21003-21015. [CrossRef] [PubMed]

124. Jiang, S.; Wessels, M.R. BsaB, a Novel Adherence Factor of Group B Streptococcus. Infect. Immun. 2014, 82, 1007-1016. [CrossRef] [PubMed]

125. Chuzeville, S.; Dramsi, S.; Madec, J.-Y.; Haenni, M.; Payot, S. Antigen I/II encoded by integrative and conjugative elements of Streptococcus agalactiae and role in biofilm formation. Microb. Pathog. 2015, 88, 1-9. [CrossRef] [PubMed]

126. Gosink, K.K.; Mann, E.R.; Guglielmo, C.; Tuomanen, E.I.; Masure, H.R. Role of Novel Choline Binding Proteins in Virulence of Streptococcus pneumoniae. Infect. Immun. 2000, 68, 5690-5695. [CrossRef]

127. Hammerschmidt, S. Adherence molecules of pathogenic pneumococci. Curr. Opin. Microbiol. 2006, 9, 12-20. [CrossRef]

128. López, R.; García, E. Recent trends on the molecular biology of pneumococcal capsules, lytic enzymes, and bacteriophage. FEMS Microbiol. Rev. 2004, 28, 553-580. [CrossRef]

129. López, R.; García, E.; García, P.; García, J.L. Cell Wall Hydrolases. Pneumococcus 2004, 75-88. [CrossRef]

130. Tokuda, M.; Okahashi, N.; Takahashi, I.; Nakai, M.; Nagaoka, S.; Kawagoe, M.; Koga, T. Complete nucleotide sequence of the gene for a surface protein antigen of Streptococcus sobrinus. Infect. Immun. 1991, 59, 3309-3312. [CrossRef]

131. LaPolla, R.J.; Haron, J.A.; Kelly, C.G.; Taylor, W.R.; Bohart, C.; Hendricks, M.; Pyati, J.P.; Graff, R.T.; Ma, J.K.; Lehner, T. Sequence and structural analysis of surface protein antigen I/II (SpaA) of Streptococcus sobrinus. Infect. Immun. 1991, 59, 2677-2685. [CrossRef]

132. Tamura, H.; Kikuchi, T.; Shirato, R.; Kato, H. Cloning and DNA sequencing of the surface protein antigen I/II (PAa) of Streptococcus cricetus. FEMS Microbiol. Lett. 2001, 196, 251-256. [CrossRef] [PubMed] 
133. Bowen, W.H.; Schilling, K.; Giertsen, E.; Pearson, S.; Lee, S.F.; Bleiweis, A.; Beeman, D. Role of a cell surface-associated protein in adherence and dental caries. Infect. Immun. 1991, 59, 4606-4609. [CrossRef] [PubMed]

134. Beg, A.M.; Jones, M.N.; Miller-Torbert, T.; Holt, R.G. Binding of Streptococcus mutans to extracellular matrix molecules and fibrinogen. Biochem. Biophys. Res. Commun. 2002, 298, 75-79. [CrossRef]

135. Pecharki, D.; Petersen, F.C.; Assev, S.; Scheie, A.A. Involvement of antigen I/II surface proteins in Streptococcus mutans and Streptococcus intermedius biofilm formation. Oral Microbiol. Immunol. 2005, 20, 366-371. [CrossRef]

136. Besingi, R.N.; Wenderska, I.B.; Senadheera, D.B.; Cvitkovitch, D.G.; Long, J.R.; Wen, Z.T.; Brady, L.J. Functional amyloids in Streptococcus mutans, their use as targets of biofilm inhibition and initial characterization of SMU_63c. Microbiology 2017, 163, 488-501. [CrossRef]

137. Lynch, D.; Fountain, T.; Mazurkiewicz, J.; Banas, J. Glucan-Binding Proteins are Essential for Shaping Streptococcus mutans Biofilm Architecture. FEMS Microbiol. Lett. 2007, 268, 158-165. [CrossRef]

138. Liang, X.; Chen, Y.-Y.M.; Ruiz, T.; Wu, H. New Cell Surface Protein Involved in Biofilm Formation by Streptococcus parasanguinis. Infect. Immun. 2011, 79, 3239-3248. [CrossRef]

139. Cho, K.H.; Caparon, M.G. Patterns of virulence gene expression differ between biofilm and tissue communities of Streptococcus pyogenes. Mol. Microbiol. 2005, 57, 1545-1556. [CrossRef]

140. Marks, L.R.; Mashburn-Warren, L.; Federle, M.J.; Hakansson, A.P. Streptococcus pyogenes Biofilm Growth In Vitro and In Vivo and Its Role in Colonization, Virulence, and Genetic Exchange. J. Infect. Dis. 2014, 210, 25-34. [CrossRef]

141. Doern, C.D.; Roberts, A.L.; Hong, W.; Nelson, J.; Lukomski, S.; Swords, W.E.; Reid, S.D. Biofilm formation by group A Streptococcus: A role for the streptococcal regulator of virulence (Srv) and streptococcal cysteine protease (SpeB). Microbiology. 2009, 155, 46-52. [CrossRef]

142. Vyas, H.K.N.; Proctor, E.-J.; McArthur, J.; Gorman, J.; Sanderson-Smith, M. Current Understanding of Group A Streptococcal Biofilms. Curr. Drug Targets 2019, 20, 982-993. [CrossRef]

143. Carroll, R.K.; Musser, J.M. From transcription to activation: How group A streptococcus, the flesh-eating pathogen, regulates SpeB cysteine protease production. Mol. Microbiol. 2011, 81, 588-601. [CrossRef]

144. Federle, M.J.; McIver, K.S.; Scott, J.R. A response regulator that represses transcription of several virulence operons in the group A streptococcus. J. Bacteriol. 1999, 181, 3649-3657. [CrossRef]

145. Graham, M.R.; Smoot, L.M.; Migliaccio, C.A.L.; Virtaneva, K.; Sturdevant, D.E.; Porcella, S.F.; Federle, M.J.; Adams, G.J.; Scott, J.R.; Musser, J.M. Virulence control in group A Streptococcus by a two-component gene regulatory system: Global expression profiling and in vivo infection modeling. Proc. Natl. Acad. Sci. USA 2002, 99, 13855-13860. [CrossRef]

146. Sugareva, V.; Arlt, R.; Fiedler, T.; Riani, C.; Podbielski, A.; Kreikemeyer, B. Serotype- and strain- dependent contribution of the sensor kinase CovS of the CovRS two-component system to Streptococcus pyogenes pathogenesis. BMC Microbiol. 2010, 10, 34. [CrossRef]

147. Podbielski, A.; Woischnik, M.; Pohl, B.; Schmidt, K.H. What is the size of the group A streptococcal vir regulon? The Mga regulator affects expression of secreted and surface virulence factors. Med. Microbiol. Immunol. 1996, 185, 171-181. [CrossRef]

148. Ribardo, D.A.; McIver, K.S. Defining the Mga regulon: Comparative transcriptome analysis reveals both direct and indirect regulation by Mga in the group A streptococcus. Mol. Microbiol. 2006, 62, 491-508. [CrossRef]

149. Hondorp, E.R.; McIver, K.S. The Mga virulence regulon: Infection where the grass is greener. Mol. Microbiol. 2007, 66, 1056-1065. [CrossRef]

150. Luo, F.; Lizano, S.; Bessen, D.E. Heterogeneity in the Polarity of Nra Regulatory Effects on Streptococcal Pilus Gene Transcription and Virulence. Infect. Immun. 2008, 76, 2490-2497. [CrossRef]

151. Lyon, W.R.; Madden, J.C.; Levin, J.C.; Stein, J.L.; Caparon, M.G. Mutation of luxS affects growth and virulence factor expression in Streptococcus pyogenes. Mol. Microbiol. 2001, 42, 145-157. [CrossRef]

152. Marouni, M.J.; Sela, S. The luxS Gene of Streptococcus pyogenes Regulates Expression of Genes That Affect Internalization by Epithelial Cells. Infect. Immun. 2003, 71, 5633-5639. [CrossRef] [PubMed]

153. Siller, M.; Janapatla, R.P.; Pirzada, Z.A.; Hassler, C.; Zinkl, D.; Charpentier, E. Functional analysis of the group A streptococcal luxS/AI-2 system in metabolism, adaptation to stress and interaction with host cells. BMC Microbiol. 2008, 8, 188. [CrossRef] [PubMed] 
154. Chang, J.C.; LaSarre, B.; Jimenez, J.C.; Aggarwal, C.; Federle, M.J. Two group A streptococcal peptide pheromones act through opposing Rgg regulators to control biofilm development. PLoS Pathog. 2011, 7, e1002190. [CrossRef]

155. Pérez-Pascual, D.; Gaudu, P.; Fleuchot, B.; Besset, C.; Rosinski-Chupin, I.; Guillot, A.; Monnet, V.; Gardan, R. RovS and its associated signaling peptide form a cell-to-cell communication system required for Streptococcus agalactiae pathogenesis. mBio 2015, 6. [CrossRef]

156. Parker, R.E.; Knupp, D.; Al Safadi, R.; Rosenau, A.; Manning, S.D. Contribution of the RgfD Quorum Sensing Peptide to rgf Regulation and Host Cell Association in Group B Streptococcus. Genes 2017, 8, 23. [CrossRef]

157. Park, S.E.; Jiang, S.; Wessels, M.R. CsrRS and Environmental pH Regulate Group B Streptococcus Adherence to Human Epithelial Cells and Extracellular Matrix. Infect. Immun. 2012, 80, 3975-3984. [CrossRef]

158. Yang, Y.; Luo, M.; Zhou, H.; Li, C.; Luk, A.; Zhao, G.; Fung, K.; Ip, M. Role of Two-Component System Response Regulator bceR in the Antimicrobial Resistance, Virulence, Biofilm Formation, and Stress Response of Group B Streptococcus. Front. Microbiol. 2019, 10, 10. [CrossRef]

159. Safadi, R.A.; Mereghetti, L.; Salloum, M.; Lartigue, M.-F.; Virlogeux-Payant, I.; Quentin, R.; Rosenau, A. Two-Component System RgfA/C Activates the fbsB Gene Encoding Major Fibrinogen-Binding Protein in Highly Virulent CC17 Clone Group B Streptococcus. PLoS ONE 2011, 6, e14658. [CrossRef]

160. Spellerberg, B.; Rozdzinski, E.; Martin, S.; Weber-Heynemann, J.; Lütticken, R. rgf Encodes a Novel Two-Component Signal Transduction System of Streptococcus agalactiae. Infect. Immun. 2002, 70, 2434-2440. [CrossRef]

161. Patras, K.A.; Derieux, J.; Al-Bassam, M.M.; Adiletta, N.; Vrbanac, A.; Lapek, J.D.; Zengler, K.; Gonzalez, D.J.; Nizet, V. Group B Streptococcus Biofilm Regulatory Protein A Contributes to Bacterial Physiology and Innate Immune Resistance. J. Infect. Dis. 2018, 218, 1641-1652. [CrossRef]

162. Vidal, J.E.; Ludewick, H.P.; Kunkel, R.M.; Zähner, D.; Klugman, K.P. The LuxS-Dependent Quorum-Sensing System Regulates Early Biofilm Formation by Streptococcus pneumoniae Strain D39. Infect. Immun. 2011, 79, 4050-4060. [CrossRef]

163. Trappetti, C.; Gualdi, L.; Meola, L.; Jain, P.; Korir, C.; Edmonds, P.; Iannelli, F.; Ricci, S.; Pozzi, G.; Oggioni, M.R. The impact of the competence quorum sensing system on Streptococcus pneumoniae biofilms varies depending on the experimental model. BMC Microbiol. 2011, 11, 75. [CrossRef]

164. Vidal, J.E.; Howery, K.E.; Ludewick, H.P.; Nava, P.; Klugman, K.P. Quorum-Sensing Systems LuxS/Autoinducer 2 and Com Regulate Streptococcus pneumoniae Biofilms in a Bioreactor with Living Cultures of Human Respiratory Cells. Infect. Immun. 2013, 81, 1341-1353. [CrossRef] [PubMed]

165. Aggarwal, S.D.; Eutsey, R.; West-Roberts, J.; Domenech, A.; Xu, W.; Abdullah, I.T.; Mitchell, A.P.; Veening, J.-W.; Yesilkaya, H.; Hiller, N.L. Function of BriC peptide in the pneumococcal competence and virulence portfolio. PLoS Pathog. 2018, 14. [CrossRef] [PubMed]

166. Cuevas, R.A.; Eutsey, R.; Kadam, A.; West-Roberts, J.A.; Woolford, C.A.; Mitchell, A.P.; Mason, K.M.; Hiller, N.L. A novel streptococcal cell-cell communication peptide promotes pneumococcal virulence and biofilm formation. Mol. Microbiol. 2017, 105, 554-571. [CrossRef]

167. Hemsley, C.; Joyce, E.; Hava, D.L.; Kawale, A.; Camilli, A. MgrA, an Orthologue of Mga, Acts as a Transcriptional Repressor of the Genes within the rlrA Pathogenicity Islet in Streptococcus pneumoniae. J. Bacteriol. 2003, 185, 6640-6647. [CrossRef] [PubMed]

168. Senadheera, D.B.; Cordova, M.; Ayala, E.A.; Chávez de Paz, L.E.; Singh, K.; Downey, J.S.; Svensäter, G.; Goodman, S.D.; Cvitkovitch, D.G. Regulation of Bacteriocin Production and Cell Death by the VicRK Signaling System in Streptococcus mutans. J. Bacteriol. 2012, 194, 1307-1316. [CrossRef]

169. Senadheera, M.D.; Guggenheim, B.; Spatafora, G.A.; Huang, Y.-C.C.; Choi, J.; Hung, D.C.I.; Treglown, J.S.; Goodman, S.D.; Ellen, R.P.; Cvitkovitch, D.G. A VicRK Signal Transduction System in Streptococcus mutans Affects gtfBCD, gbpB, and ftf Expression, Biofilm Formation, and Genetic Competence Development. J. Bacteriol. 2005, 187, 4064-4076. [CrossRef]

170. Duque, C.; Stipp, R.N.; Wang, B.; Smith, D.J.; Höfling, J.F.; Kuramitsu, H.K.; Duncan, M.J.; Mattos-Graner, R.O. Downregulation of GbpB, a Component of the VicRK Regulon, Affects Biofilm Formation and Cell Surface Characteristics of Streptococcus mutans. Infect. Immun. 2011, 79, 786-796. [CrossRef]

171. Ayala, E.; Downey, J.S.; Mashburn-Warren, L.; Senadheera, D.B.; Cvitkovitch, D.G.; Goodman, S.D. A Biochemical Characterization of the DNA Binding Activity of the Response Regulator VicR from Streptococcus mutans. PLoS ONE 2014, 9. [CrossRef] 
172. Qi, F.; Merritt, J.; Lux, R.; Shi, W. Inactivation of the ciaH Gene in Streptococcus mutans diminishes mutacin production and competence development, alters sucrose-dependent biofilm formation, and reduces stress tolerance. Infect. Immun. 2004, 72, 4895-4899. [CrossRef] [PubMed]

173. Ahn, S.-J.; Lemos, J.A.C.; Burne, R.A. Role of HtrA in Growth and Competence of Streptococcus mutans UA159. J. Bacteriol. 2005, 187, 3028-3038. [CrossRef] [PubMed]

174. Biswas, S.; Biswas, I. Role of HtrA in Surface Protein Expression and Biofilm Formation by Streptococcus mutans. Infect. Immun. 2005, 73, 6923-6934. [CrossRef] [PubMed]

175. Ahn, S.-J.; Wen, Z.; Burne, R. Multilevel Control of Competence Development and Stress Tolerance in Streptococcus mutans UA159. Infect. Immun. 2006, 74, 1631-1642. [CrossRef]

176. Idone, V.; Brendtro, S.; Gillespie, R.; Kocaj, S.; Peterson, E.; Rendi, M.; Warren, W.; Michalek, S.; Krastel, K.; Cvitkovitch, D.; et al. Effect of an orphan response regulator on Streptococcus mutans sucrose-dependent adherence and cariogenesis. Infect. Immun. 2003, 71, 4351-4360. [CrossRef]

177. Biswas, S.; Biswas, I. Regulation of the glucosyltransferase (gtfBC) operon by CovR in Streptococcus mutans. J. Bacteriol. 2006, 188, 988-998. [CrossRef]

178. Wen, Z.T.; Burne, R.A. LuxS-Mediated Signaling in Streptococcus mutans Is Involved in Regulation of Acid and Oxidative Stress Tolerance and Biofilm Formation. J. Bacteriol. 2004, 186, 2682-2691. [CrossRef]

179. He, Z.; Liang, J.; Tang, Z.; Ma, R.; Peng, H.; Huang, Z. Role of the luxS gene in initial biofilm formation by Streptococcus mutans. J. Mol. Microbiol. Biotechnol. 2015, 25, 60-68. [CrossRef]

180. Leung, V.; Dufour, D.; Lévesque, C.M. Death and survival in Streptococcus mutans: Differing outcomes of a quorum-sensing signaling peptide. Front. Microbiol. 2015, 6. [CrossRef]

181. Li, Y.-H.; Tang, N.; Aspiras, M.B.; Lau, P.C.Y.; Lee, J.H.; Ellen, R.P.; Cvitkovitch, D.G. A Quorum-Sensing Signaling System Essential for Genetic Competence in Streptococcus mutans Is Involved in Biofilm Formation. J. Bacteriol. 2002, 184, 2699-2708. [CrossRef]

182. Wen, Z.T.; Baker, H.V.; Burne, R.A. Influence of BrpA on Critical Virulence Attributes of Streptococcus mutans. J. Bacteriol. 2006, 188, 2983-2992. [CrossRef] [PubMed]

183. Bitoun, J.P.; Liao, S.; Yao, X.; Ahn, S.-J.; Isoda, R.; Nguyen, A.H.; Brady, L.J.; Burne, R.A.; Abranches, J.; Wen, Z.T. BrpA Is Involved in Regulation of Cell Envelope Stress Responses in Streptococcus mutans. Appl. Environ. Microbiol. 2012, 78, 2914-2922. [CrossRef] [PubMed]

184. Wang, C.; Hou, J.; van der Mei, H.C.; Busscher, H.J.; Ren, Y. Emergent Properties in Streptococcus mutans Biofilms Are Controlled through Adhesion Force Sensing by Initial Colonizers. mBio 2019, 10. [CrossRef] [PubMed]

185. Wen, Z.T.; Suntharaligham, P.; Cvitkovitch, D.G.; Burne, R.A. Trigger Factor in Streptococcus mutans Is Involved in Stress Tolerance, Competence Development, and Biofilm Formation. Infect. Immun. 2005, 73, 219-225. [CrossRef]

186. Mao, M.-Y.; Li, M.; Lei, L.; Yin, J.-X.; Yang, Y.-M.; Hu, T. The Regulator Gene rnc Is Closely Involved in Biofilm Formation in Streptococcus mutans. Caries Res. 2018, 52, 347-358. [CrossRef]

187. Mao, M.-Y.; Yang, Y.-M.; Li, K.-Z.; Lei, L.; Li, M.; Yang, Y.; Tao, X.; Yin, J.-X.; Zhang, R.; Ma, X.-R.; et al. The rnc Gene Promotes Exopolysaccharide Synthesis and Represses the vicRKX Gene Expressions via MicroRNA-Size Small RNAs in Streptococcus mutans. Front. Microbiol. 2016, 7. [CrossRef]

188. Li, Z.; Xiang, Z.; Zeng, J.; Li, Y.; Li, J. A GntR Family Transcription Factor in Streptococcus mutans Regulates Biofilm Formation and Expression of Multiple Sugar Transporter Genes. Front. Microbiol. 2019, 9, 3224. [CrossRef]

189. Kawada-Matsuo, M.; Mazda, Y.; Oogai, Y.; Kajiya, M.; Kawai, T.; Yamada, S.; Miyawaki, S.; Oho, T.; Komatsuzawa, H. GlmS and NagB Regulate Amino Sugar Metabolism in Opposing Directions and Affect Streptococcus mutans Virulence. PLoS ONE 2012, 7. [CrossRef]

190. Zeng, L.; Burne, R.A. NagR Differentially Regulates the Expression of the glmS and nagAB Genes Required for Amino Sugar Metabolism by Streptococcus mutans. J. Bacteriol. 2015, 197, 3533-3544. [CrossRef]

191. Blehert, D.S.; Palmer, R.J.; Xavier, J.B.; Almeida, J.S.; Kolenbrander, P.E. Autoinducer 2 Production by Streptococcus gordonii DL1 and the Biofilm Phenotype of a luxS Mutant Are Influenced by Nutritional Conditions. J. Bacteriol. 2003, 185, 4851-4860. [CrossRef]

192. Zheng, L.; Chen, Z.; Itzek, A.; Herzberg, M.C.; Kreth, J. CcpA Regulates Biofilm Formation and Competence in Streptococcus gordonii. Mol. Oral Microbiol. 2012, 27, 83-94. [CrossRef] [PubMed] 
193. Liu, J.; Stone, V.N.; Ge, X.; Tang, M.; Elrami, F.; Xu, P. TetR Family Regulator brpT Modulates Biofilm Formation in Streptococcus sanguinis. PLoS ONE 2017, 12. [CrossRef] [PubMed]

194. Wang, Y.; Wang, Y.; Liu, B.; Wang, S.; Li, J.; Gong, S.; Sun, L.; Yi, L. pdh modulate virulence through reducing stress tolerance and biofilm formation of Streptococcus suis serotype 2. Virulence 2019, 10, 588-599. [CrossRef] [PubMed]

195. Camargo, T.M.; Stipp, R.N.; Alves, L.A.; Harth-Chu, E.N.; Höfling, J.F.; Mattos-Graner, R.O. Novel Two-Component System of Streptococcus sanguinis Affecting Functions Associated with Viability in Saliva and Biofilm Formation. Infect. Immun. 2018, 86, e00942-17. [CrossRef]

196. Ge, X.; Kitten, T.; Chen, Z.; Lee, S.P.; Munro, C.L.; Xu, P. Identification of Streptococcus sanguinis Genes Required for Biofilm Formation and Examination of Their Role in Endocarditis Virulence. Infect. Immun. 2008, 76, 2551-2559. [CrossRef]

197. Yadav, M.K.; Vidal, J.E.; Go, Y.Y.; Kim, S.H.; Chae, S.-W.; Song, J.-J. The LuxS/AI-2 Quorum-Sensing System of Streptococcus pneumoniae Is Required to Cause Disease, and to Regulate Virulence- and Metabolism-Related Genes in a Rat Model of Middle Ear Infection. Front. Cell. Infect. Microbiol. 2018, 8, 138. [CrossRef]

198. Liu, B.; Yi, L.; Li, J.; Wang, Y.; Mao, C.; Wang, Y. Autoinducer-2 influences tetracycline resistance in Streptococcus suis by regulating the tet(M) gene via transposon Tn916. Res. Vet. Sci. 2020, 128, 269-274. [CrossRef]

199. Wang, Y.; Wang, Y.; Sun, L.; Grenier, D.; Yi, L. The LuxS/AI-2 system of Streptococcus suis. Appl. Microbiol. Biotechnol. 2018, 102, 7231-7238. [CrossRef]

200. Suntharalingam, P.; Cvitkovitch, D.G. Quorum sensing in streptococcal biofilm formation. Trends Microbiol. 2005, 13, 3-6. [CrossRef]

201. Stipp, R.N.; Boisvert, H.; Smith, D.J.; Höfling, J.F.; Duncan, M.J.; Mattos-Graner, R.O. CovR and VicRK Regulate Cell Surface Biogenesis Genes Required for Biofilm Formation in Streptococcus mutans. PLoS ONE 2013, 8, e58271. [CrossRef]

202. Tang, B.; Gong, T.; Zhou, X.; Lu, M.; Zeng, J.; Peng, X.; Wang, S.; Li, Y. Deletion of cas3 gene in Streptococcus mutans affects biofilm formation and increases fluoride sensitivity. Arch. Oral Biol. 2019, 99, 190-197. [CrossRef] [PubMed]

203. Mascher, T.; Zähner, D.; Merai, M.; Balmelle, N.; de Saizieu, A.; Hakenbeck, R. The Streptococcus pneumoniae cia Regulon: CiaR Target Sites and Transcription Profile Analysis. J. Bacteriol. 2003, 185, 60-70. [CrossRef] [PubMed]

204. Chan, W.T.; Domenech, M.; Moreno-Córdoba, I.; Navarro-Martínez, V.; Nieto, C.; Moscoso, M.; García, E.; Espinosa, M. The Streptococcus pneumoniae yefM-yoeB and relBE Toxin-Antitoxin Operons Participate in Oxidative Stress and Biofilm Formation. Toxins 2018, 10, 378. [CrossRef] [PubMed]

205. Li, Y.-H.; Lau, P.C.Y.; Tang, N.; Svensäter, G.; Ellen, R.P.; Cvitkovitch, D.G. Novel Two-Component Regulatory System Involved in Biofilm Formation and Acid Resistance in Streptococcus mutans. J. Bacteriol. 2002, 184, 6333-6342. [CrossRef]

206. Tian, X.-L.; Salim, H.; Dong, G.; Parcells, M.; Li, Y.-H. The BceABRS four-component system that is essential for cell envelope stress response is involved in sensing and response to host defence peptides and is required for the biofilm formation and fitness of Streptococcus mutans. J. Med. Microbiol. 2018, 67, 874-883. [CrossRef]

207. Li, Y.; Burne, R.A. Regulation of the gtfBC and $\mathrm{ftf}$ genes of Streptococcus mutans in biofilms in response to pH and carbohydrate. Microbiol. Read. Engl. 2001, 147, 2841-2848. [CrossRef]

208. Banas, J.A. Virulence properties of Streptococcus mutans. Front. Biosci. 2004, 9, 1267. [CrossRef]

209. Krzyściak, W.; Jurczak, A.; Kościelniak, D.; Bystrowska, B.; Skalniak, A. The virulence of Streptococcus mutans and the ability to form biofilms. Eur. J. Clin. Microbiol. Infect. Dis. 2014, 33, 499-515. [CrossRef]

210. Wen, Z.T.; Burne, R.A. Functional Genomics Approach to Identifying Genes Required for Biofilm Development by Streptococcus mutans. Appl. Environ. Microbiol. 2002, 68, 9. [CrossRef]

211. Shadbad, M.A.; Kafil, H.S.; Rezaee, M.A.; Farzami, M.R.; Dehkharghani, A.D.; Sadeghi, J.; Gholizadeh, P.; Aghazadeh, M. Filament genes and biofilm formation in Streptococcus agalactiae: Rev. Med. Microbiol. 2020, 31, 17-25. [CrossRef]

212. Froeliger, E.H.; Fives-Taylor, P. Streptococcus parasanguis fimbria-associated adhesin fap1 is required for biofilm formation. Infect. Immun. 2001, 69, 2512-2519. [CrossRef] [PubMed] 
213. Sanchez, C.; Shivshankar, P.; Stol, K.; Trakhtenbroit, S.; Sullam, P.; Sauer, K.; Hermans, P.; Orihuela, J. The Pneumococcal Serine-Rich Repeat Protein Is an Intra-Species Bacterial Adhesin That Promotes Bacterial Aggregation In Vivo and in Biofilms. PLoS Pathog. 2010, 6, e1001044. [CrossRef]

214. Spellerberg, B.; Cundell, D.R.; Sandros, J.; Pearce, B.J.; Idänpään-Heikkilä, I.; Rosenow, C.; Masure, H.R. Pyruvate oxidase, as a determinant of virulence in Streptococcus pneumoniae. Mol. Microbiol. 1996, 19, 803-813. [CrossRef] [PubMed]

215. Parker, D.; Soong, G.; Planet, P.; Brower, J.; Ratner, A.J.; Prince, A. The NanA Neuraminidase of Streptococcus pneumoniae Is Involved in Biofilm Formation. Infect. Immun. 2009, 77, 3722-3730. [CrossRef] [PubMed]

216. Domenech, M.; García, E. The N-Acetylglucosaminidase LytB of Streptococcus pneumoniae Is Involved in the Structure and Formation of Biofilms. Appl. Environ. Microbiol. 2020, 86, e00280-20. [CrossRef]

217. Babbar, A.; Barrantes, I.; Pieper, D.H.; Itzek, A. Superantigen SpeA attenuates the biofilm forming capacity of Streptococcus pyogenes. J. Microbiol. 2019, 57, 626-636. [CrossRef]

218. Wu, H.; Moser, C.; Wang, H.-Z.; Høiby, N.; Song, Z.-J. Strategies for combating bacterial biofilm infections. Int. J. Oral Sci. 2015, 7, 1-7. [CrossRef]

219. Lovetri, K.; Madhyastha, S. Antimicrobial and Antibiofilm Activity of Quorum Sensing Peptides and Peptide Analogues Against Oral Biofilm Bacteria. Methods Mol. Biol. 2010, 618, 383-392. [CrossRef]

220. Vijayakumar, K.; Ramanathan, T. Antiquorum sensing and biofilm potential of 5- Hydroxymethylfurfural against Gram positive pathogens. Microb. Pathog. 2018, 125, 48-50. [CrossRef]

221. Cook, L.C.; Federle, M.J. Peptide pheromone signaling in Streptococcus and Enterococcus. FEMS Microbiol. Rev. 2014, 38, 473-492. [CrossRef]

222. Mah, T.F.; O'Toole, G.A. Mechanisms of biofilm resistance to antimicrobial agents. Trends Microbiol. 2001, 9, 34-39. [CrossRef]

223. Mulcahy, H.; Charron-Mazenod, L.; Lewenza, S. Extracellular DNA chelates cations and induces antibiotic resistance in Pseudomonas aeruginosa biofilms. PLoS Pathog. 2008, 4, e1000213. [CrossRef] [PubMed]

224. Craigen, B.; Dashiff, A.; Kadouri, D.E. The Use of Commercially Available Alpha-Amylase Compounds to Inhibit and Remove Staphylococcus aureus Biofilms. Open Microbiol. J. 2011, 5, 21-31. [CrossRef] [PubMed]

225. Ramasubbu, N.; Ragunath, C.; Sundar, K.; Mishra, P.; Gyémánt, G.; Kandra, L. Structure-function relationships in human salivary $\alpha$-amylase: Role of aromatic residues. Biologia 2005, 60, 47-56.

226. Darouiche, R.O.; Mansouri, M.D.; Gawande, P.V.; Madhyastha, S. Antimicrobial and antibiofilm efficacy of triclosan and DispersinB combination. J. Antimicrob. Chemother. 2009, 64, 88-93. [CrossRef]

227. Alkawash, M.A.; Soothill, J.S.; Schiller, N.L. Alginate lyase enhances antibiotic killing of mucoid Pseudomonas aeruginosa in biofilms. APMIS Acta Pathol. Microbiol. Immunol. Scand. 2006, 114, 131-138. [CrossRef]

228. Kaplan, J.B. Therapeutic Potential of Biofilm-Dispersing Enzymes: Int. J. Artif. Organs 2018. [CrossRef]

229. Leroy, C.; Delbarre, C.; Ghillebaert, F.; Compere, C.; Combes, D. Effects of commercial enzymes on the adhesion of a marine biofilm-forming bacterium. Biofouling 2008, 24, 11-22. [CrossRef]

230. Koo, H.; Allan, R.N.; Howlin, R.P.; Hall-Stoodley, L.; Stoodley, P. Targeting microbial biofilms: Current and prospective therapeutic strategies. Nat. Rev. Microbiol. 2017, 15, 740-755. [CrossRef]

231. Ren, Z.; Cui, T.; Zeng, J.; Chen, L.; Zhang, W.; Xu, X.; Cheng, L.; Li, M.; Li, J.; Zhou, X.; et al. Molecule Targeting Glucosyltransferase Inhibits Streptococcus mutans Biofilm Formation and Virulence. Antimicrob. Agents Chemother. 2015, 60, 126-135. [CrossRef]

232. Pletzer, D.; Hancock, R.E.W. Antibiofilm Peptides: Potential as Broad-Spectrum Agents. J. Bacteriol. 2016, 198, 2572-2578. [CrossRef] [PubMed]

233. de la Fuente-Núñez, C.; Korolik, V.; Bains, M.; Nguyen, U.; Breidenstein, E.B.M.; Horsman, S.; Lewenza, S.; Burrows, L.; Hancock, R.E.W. Inhibition of Bacterial Biofilm Formation and Swarming Motility by a Small Synthetic Cationic Peptide. Antimicrob. Agents Chemother. 2012, 56, 2696-2704. [CrossRef] [PubMed]

234. de la Fuente-Núñez, C.; Reffuveille, F.; Mansour, S.C.; Reckseidler-Zenteno, S.L.; Hernández, D.; Brackman, G.; Coenye, T.; Hancock, R.E.W. D-Enantiomeric Peptides that Eradicate Wild-Type and Multidrug-Resistant Biofilms and Protect against Lethal Pseudomonas aeruginosa Infections. Chem. Biol. 2015, 22, 196-205. [CrossRef] [PubMed]

235. Wang, W.; Tao, R.; Tong, Z.; Ding, Y.; Kuang, R.; Zhai, S.; Liu, J.; Ni, L. Effect of a novel antimicrobial peptide chrysophsin-1 on oral pathogens and Streptococcus mutans biofilms. Peptides 2012, 33, 212-219. [CrossRef] [PubMed] 
236. Tao, R.; Tong, Z.; Lin, Y.; Xue, Y.; Wang, W.; Kuang, R.; Wang, P.; Tian, Y.; Ni, L. Antimicrobial and antibiofilm activity of pleurocidin against cariogenic microorganisms. Peptides 2011, 32, 1748-1754. [CrossRef]

237. Cao, Y.; Yin, H.; Wang, W.; Pei, P.; Wang, Y.; Wang, X.; Jiang, J.; Luo, S.-Z.; Chen, L. Killing Streptococcus mutans in mature biofilm with a combination of antimicrobial and antibiofilm peptides. Amino Acids 2020, 52,1-14. [CrossRef]

238. Guo, L.; McLean, J.S.; Yang, Y.; Eckert, R.; Kaplan, C.W.; Kyme, P.; Sheikh, O.; Varnum, B.; Lux, R.; Shi, W.; et al. Precision-guided antimicrobial peptide as a targeted modulator of human microbial ecology. Proc. Natl. Acad. Sci. USA 2015, 112, 7569-7574. [CrossRef]

239. Shahrour, H.; Ferrer-Espada, R.; Dandache, I.; Bárcena-Varela, S.; Sánchez-Gómez, S.; Chokr, A.; Martinez-de-Tejada, G. AMPs as Anti-biofilm agents for human therapy and prophylaxis. In Antimicrobial Peptides; Matsuzaki, K., Ed.; Advances in Experimental Medicine and Biology; Springer Singapore: Singapore, 2019; Volume 1117, pp. 257-279. ISBN 9789811335877.

240. Field, D.; Seisling, N.; Cotter, P.; Ross, R.; Hill, C. Synergistic Nisin-Polymyxin Combinations for the Control of Pseudomonas Biofilm Formation. Front. Microbiol. 2016, 7. [CrossRef]

241. Kajwadkar, R.; Shin, J.M.; Lin, G.-H.; Fenno, J.C.; Rickard, A.H.; Kapila, Y.L. High-purity Nisin Alone or in Combination with Sodium Hypochlorite Is Effective against Planktonic and Biofilm Populations of Enterococcus faecalis. J. Endod. 2017, 43, 989-994. [CrossRef] [PubMed]

242. Yamakami, K.; Tsumori, H.; Sakurai, Y.; Shimizu, Y.; Nagatoshi, K.; Sonomoto, K. Sustainable inhibition efficacy of liposome-encapsulated nisin on insoluble glucan-biofilm synthesis by Streptococcus mutans. Pharm. Biol. 2013, 51, 267-270. [CrossRef] [PubMed]

243. Tong, Z.; Zhang, L.; Ling, J.; Jian, Y.; Huang, L.; Deng, D. An In Vitro Study on the Effect of Free Amino Acids Alone or in Combination with Nisin on Biofilms as well as on Planktonic Bacteria of Streptococcus mutans. PLoS ONE 2014, 9. [CrossRef] [PubMed]

244. Rukavina, Z.; Vanić, Ž. Current Trends in Development of Liposomes for Targeting Bacterial Biofilms. Pharmaceutics 2016, 8, 18. [CrossRef] [PubMed]

245. Gao, L.; Liu, Y.; Kim, D.; Li, Y.; Hwang, G.; Naha, P.C.; Cormode, D.P.; Koo, H. Nanocatalysts promote Streptococcus mutans biofilm matrix degradation and enhance bacterial killing to suppress dental caries in vivo. Biomaterials 2016, 101, 272-284. [CrossRef] [PubMed]

246. Kim, J.S.; Kuk, E.; Yu, K.N.; Kim, J.-H.; Park, S.J.; Lee, H.J.; Kim, S.H.; Park, Y.K.; Park, Y.H.; Hwang, C.-Y.; et al. Antimicrobial effects of silver nanoparticles. Nanomed. Nanotechnol. Biol. Med. 2007, 3, 95-101. [CrossRef]

247. Allaker, R.P. The use of nanoparticles to control oral biofilm formation. J. Dent. Res. 2010, 89, 1175-1186. [CrossRef]

248. Fernandes, T.; Bhavsar, C.; Sawarkar, S.; D'souza, A. Current and novel approaches for control of dental biofilm. Int. J. Pharm. 2018, 536, 199-210. [CrossRef]

249. Ramazanzadeh, B.; Jahanbin, A.; Yaghoubi, M.; Shahtahmassbi, N.; Ghazvini, K.; Shakeri, M.; Shafaee, H. Comparison of Antibacterial Effects of $\mathrm{ZnO}$ and $\mathrm{CuO}$ Nanoparticles Coated Brackets against Streptococcus Mutans. J. Dent. Shiraz Iran 2015, 16, 200-205.

250. Al-Adham, I.S.I.; Dinning, A.J.; Eastwood, I.M.; Austin, P.; Collier, P.J. Cell membrane effects of some common biocides. J. Ind. Microbiol. Biotechnol. 1998, 21, 6-10. [CrossRef]

251. Van Hamme, J.D.; Singh, A.; Ward, O.P. Physiological aspects. Part 1 in a series of papers devoted to surfactants in microbiology and biotechnology. Biotechnol. Adv. 2006, 24, 604-620. [CrossRef]

252. Boles, B.R.; Thoendel, M.; Singh, P.K. Rhamnolipids mediate detachment of Pseudomonas aeruginosa from biofilms. Mol. Microbiol. 2005, 57, 1210-1223. [CrossRef]

253. Chen, X.; Stewart, P.S. Biofilm removal caused by chemical treatments. Water Res. 2000, 34, 4229-4233. [CrossRef]

254. Simões, M.; Pereira, M.O.; Vieira, M.J. Effect of mechanical stress on biofilms challenged by different chemicals. Water Res. 2005, 39, 5142-5152. [CrossRef] [PubMed]

255. Bansal, T.; Englert, D.; Lee, J.; Hegde, M.; Wood, T.K.; Jayaraman, A. Differential Effects of Epinephrine, Norepinephrine, and Indole on Escherichia coli O157:H7 Chemotaxis, Colonization, and Gene Expression. Infect. Immun. 2007, 75, 4597-4607. [CrossRef] [PubMed]

256. Guo, Z.; Lin, H.; Ji, X.; Yan, G.; Lei, L.; Han, W.; Gu, J.; Huang, J. Therapeutic applications of lytic phages in human medicine. Microb. Pathog. 2020, 142, 104048. [CrossRef] [PubMed] 
257. Shen, Y.; Köller, T.; Kreikemeyer, B.; Nelson, D.C. Rapid degradation of Streptococcus pyogenes biofilms by PlyC, a bacteriophage-encoded endolysin. J. Antimicrob. Chemother. 2013, 68, 1818-1824. [CrossRef] [PubMed]

258. Meng, X.; Shi, Y.; Ji, W.; Meng, X.; Zhang, J.; Wang, H.; Lu, C.; Sun, J.; Yan, Y. Application of a Bacteriophage Lysin To Disrupt Biofilms Formed by the Animal Pathogen Streptococcus suis. Appl. Environ. Microbiol. 2011, 77, 8272-8279. [CrossRef] [PubMed]

259. Wang, M.; Xiong, W.; Liu, P.; Xie, X.; Zeng, J.; Sun, Y.; Zeng, Z. Metagenomic Insights Into the Contribution of Phages to Antibiotic Resistance in Water Samples Related to Swine Feedlot Wastewater Treatment. Front. Microbiol. 2018, 9, 2474. [CrossRef]

260. Dalmasso, M.; de Haas, E.; Neve, H.; Strain, R.; Cousin, F.J.; Stockdale, S.R.; Ross, R.P.; Hill, C. Isolation of a Novel Phage with Activity against Streptococcus mutans Biofilms. PLoS ONE 2015, 10. [CrossRef]

261. Yang, H.; Bi, Y.; Shang, X.; Wang, M.; Linden, S.B.; Li, Y.; Li, Y.; Nelson, D.C.; Wei, H. Antibiofilm Activities of a Novel Chimeolysin against Streptococcus mutans under Physiological and Cariogenic Conditions. Antimicrob. Agents Chemother. 2016, 60, 7436-7443. [CrossRef]

Publisher's Note: MDPI stays neutral with regard to jurisdictional claims in published maps and institutional affiliations.

(C) 2020 by the authors. Licensee MDPI, Basel, Switzerland. This article is an open access article distributed under the terms and conditions of the Creative Commons Attribution (CC BY) license (http://creativecommons.org/licenses/by/4.0/). 